\title{
PREDICTING ADVERSE EVENTS IN A FORENSIC PSYCHIATRIC POPULATION: A DEVELOPMENTAL APPROACH \\ by
}

\author{
Sofija Lavrinsek \\ B.Sc. University of Ottawa, 2016 \\ A thesis \\ presented to Ryerson University \\ in partial fulfillment of the \\ requirements for the degree of \\ Master of Arts \\ in the program of \\ Psychology
}

Toronto, Ontario, Canada, 2019

(C) Sofija Lavrinsek, 2019 


\section{AUTHOR'S DECLARATION FOR ELECTRONIC SUBMISSION OF A THESIS}

I hereby declare that I am the sole author of this thesis. This is a true copy of the thesis, including any required final revisions, as accepted by my examiners.

I authorize Ryerson University to lend this thesis to other institutions or individuals for the purpose of scholarly research

I further authorize Ryerson University to reproduce this thesis by photocopying or by other means, in total or in part, at the request of other institutions or individuals for the purpose of scholarly research.

I understand that my thesis may be made electronically available to the public. 
Predicting adverse events in a forensic psychiatric population: A developmental approach

$$
\begin{gathered}
\text { Master of Arts, } 2019 \\
\text { Sofija Lavrinsek } \\
\text { Clinical Psychology } \\
\text { Ryerson University }
\end{gathered}
$$

\begin{abstract}
While adverse events such as inpatient violence, recidivism, and readmission to hospital are extremely common among individuals found not criminally responsible on account of mental disorder (NCRMD), very little is known about developmental risk factors that predict these adverse events in this population. Developmental risk factor research (RFR) focuses on childhood risk factors and later outcomes, and allows for establishing a timeline for events, experiences, and the onset of behaviours or illnesses. The present study is a retrospective file review of inpatients and outpatients at Forensic Mental Health Hospital in South Central Ontario who have been found NCRMD. Developmental risk factors that have been found to predict adverse events in criminal, psychiatric, and forensic psychiatric populations, and adverse events over the period of 1 year were coded. Overall, risk factors occurring in childhood did not predict adverse events. Risk factors occurring in adolescence, specifically trauma, abuse or neglect, predicted adverse events.
\end{abstract}




\section{Acknowledgements}

I would like to thank my thesis supervisor, Dr. David Day, for his support and guidance. I would also like to express my gratitude to Dr. Alasdair Goodwill and Dr. Stephanie Penney for valuable contributions which improved this thesis greatly. Thank you to Dr. Todd Girard for sitting on my committee and Dr. Behrang Keshavarz for chairing my defence.

A special thank you goes to my peers, Amy Beaudry, Jennifer Ip, and Nicole Carmona who provided support and helpful input throughout this process.

I am eternally grateful to my mother, Mirjana Popovic-Lavrinsek, my partner, Mathew Sypher, and my dog Gwendolyn for their encouragement, advice, and inspiration. 


\section{Table of Contents}

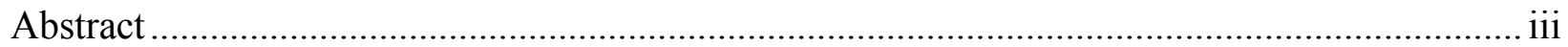

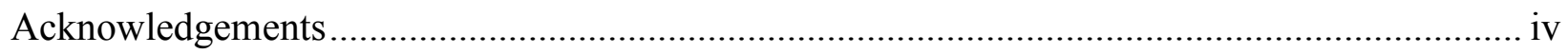

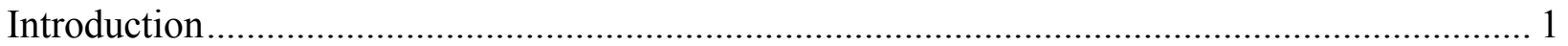

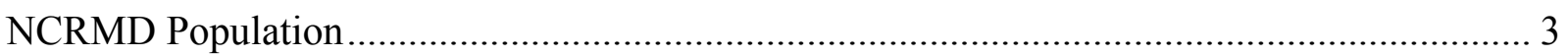

Developmental Risk Factor Research and Criminal Offending .......................................... 4

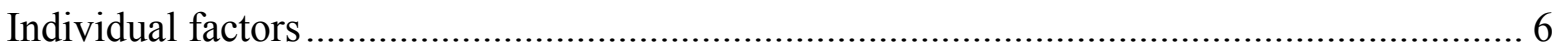

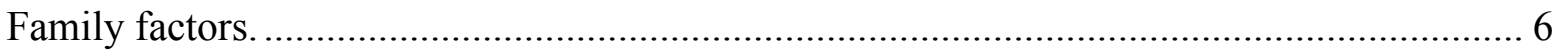

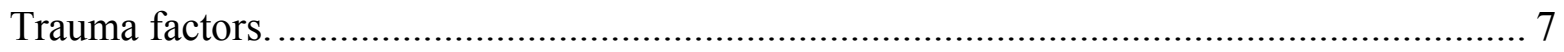

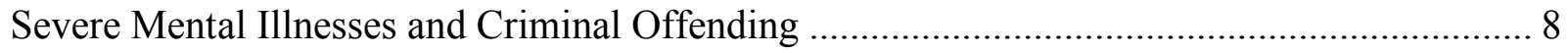

Adverse Events in Forensic Psychiatric Populations ........................................................... 9

Childhood Predictors of Outcomes in Forensic Psychiatric Populations.............................. 11

Childhood Predictors of Outcomes in Psychiatric Populations ............................................ 14

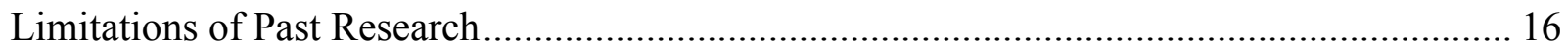

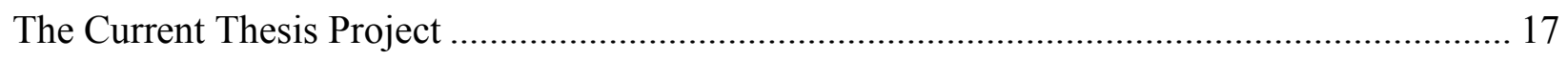

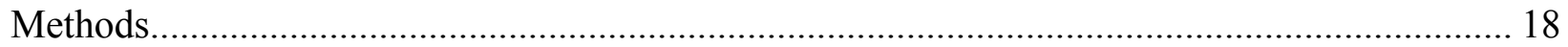

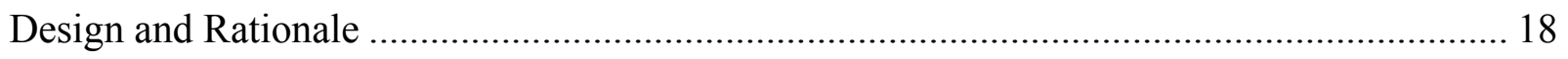

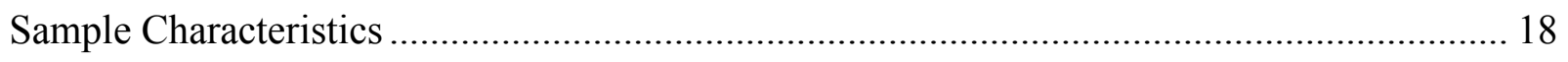

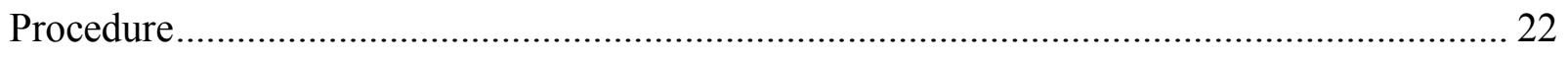

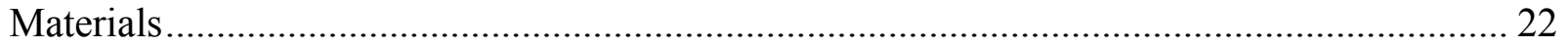

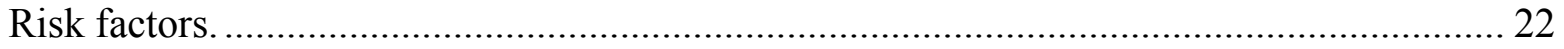

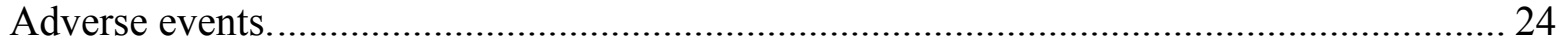

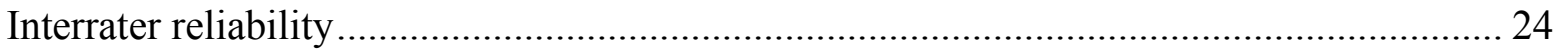

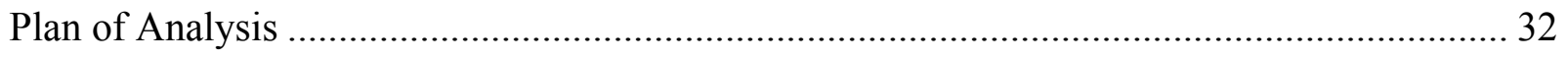

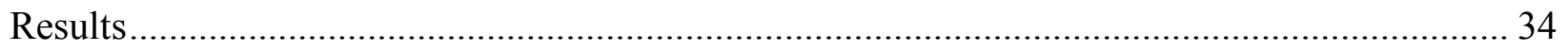




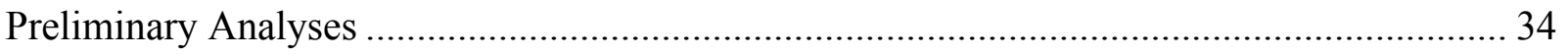

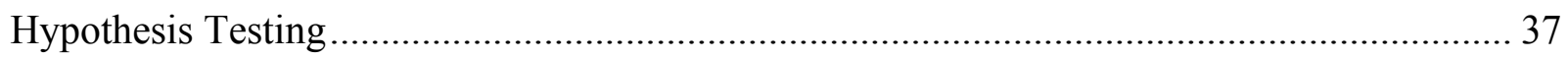

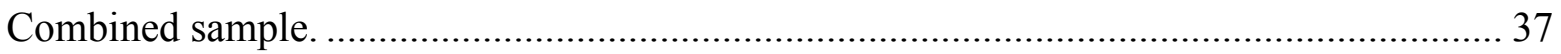

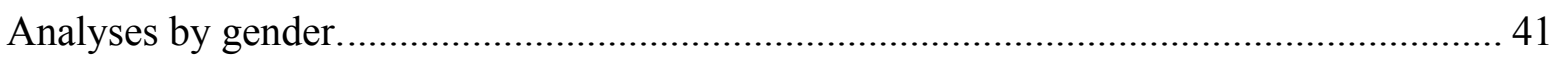

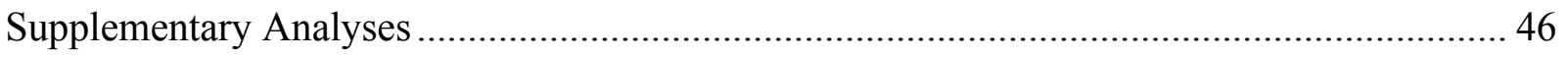

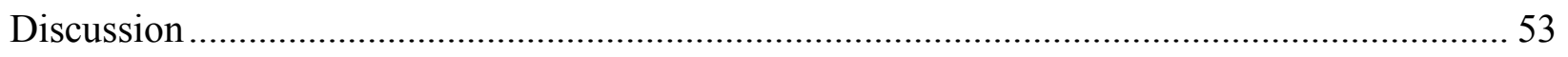

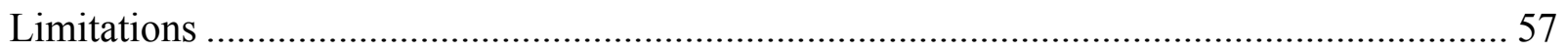

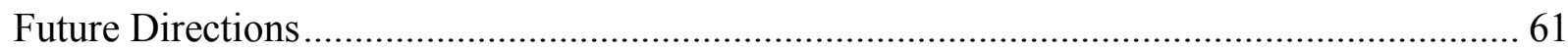

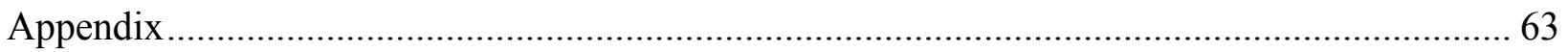

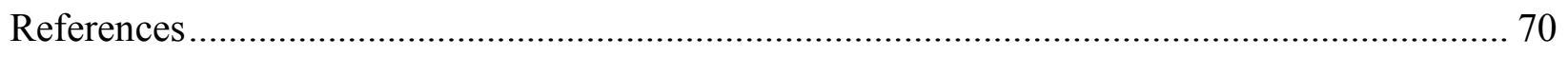




\section{List of Tables}

Table 1: Criminal and Clinical Characteristics Comparing those who Experienced an Adverse

Event and Those who did Not

Table 2: Criminal and Clinical Characteristics for Combined Sample and Comparing Males and

Females

Table 3: Inter-Rater Reliability for the Childhood and Adolescent Risk Factors 25

Table 4: Frequencies of Developmental Risk Factors for the Combined Sample and Males and

Females Separately.

Table 5: Frequencies of Adverse Events for the Combined Sample and Males and Females

Separately.....

Table 6: Cross Tabulation of Childhood Risk Factors and Any Adverse Event for the Combined

Sample

Table 7: Cross Tabulation of Adolescent Risk Factors and Any Adverse Event for the Combined

Sample

Table 8: Logistic Regression of Childhood Risk Factors and Any Adverse Event for the Combined Sample.

Table 9: Logistic Regression of Adolescent Risk Factors and Any Adverse Event for the Combined Sample

Table 10: Logistic Regression of Adolescent Risk Factors and Any Adverse Event for the Combined Sample Controlling for HCR-20 Total Score.

Table 11: Cross Tabulation of Childhood Risk Factors and Any Adverse Event for Male

Patients 
Table 12: Cross Tabulation of Adolescent Risk Factors and Any Adverse Event for Male Patients

Table 13: Cross Tabulation of Childhood Risk Factors and Any Adverse Event for Female Patients.

Table 14: Cross Tabulation of Adolescent Risk Factors and Any Adverse Event for Female

Patients.

Table 15: Logistic Regression of Childhood Risk Factors and Any Adverse Event for Male

Patients

Table 16: Logistic Regression of Adolescent Risk Factors and Any Adverse Event for Male

Patients

Table 17: Logistic Regression of Childhood Risk Factors and Any Adverse Event for Female Patients

Table 18: Logistic Regression of Adolescent Risk Factors and Any Adverse Event for Female Patients.

Table 19: Logistic Regression of Childhood Risk Factors and Substance Abuse Relapses for the Combined Sample. .46

Table 20: Logistic Regression of Childhood Risk Factors and Medication Nonadherence or Refusal for the Combined Sample...

Table 21: Logistic Regression of Childhood Risk Factors and Placement in Seclusion for the Combined Sample

Table 22: Logistic Regression of Childhood Risk Factors and Verbal or Physical Violence for the Combined Sample. 
Table 23: Logistic Regression of Childhood Risk Factors and Conflict with Staff or Patients for the Combined Sample .............................................................48

Table 24: Logistic Regression of Childhood Risk Factors and being AWOL for the Combined Sample.

Table 25: Logistic Regression of Adolescent Risk Factors and Placement in Seclusion for the Combined Sample

Table 26: Logistic Regression of Adolescent Risk Factors and Verbal or Physical Violence for the Combined Sample.

Table 27: Logistic Regression of Adolescent Risk Factors Substance Abuse Relapses for the Combined Sample.

Table 28: Logistic Regression of Adolescent Risk Factors and being AWOL for the Combined Sample..... 


\section{Introduction}

Adverse events such as violence, treatment non-compliance, substance use, victimization, recidivism, and readmission to hospital are extremely common in forensic psychiatric populations (Broderick, Azizian, Kornbluh, \& Warburton, 2015; Charette et al., 2015; Coid, Hickey, Kahtan, Zhang, \& Yang, 2007; De Vries Robbé, de Vogel, Douglas, \& Nijman, 2015; Harris, Rice, \& Quinsey, 1993; Hoptman, Yates, Patalinjug, Wack, \& Convit, 1999; Linhorst \& Scott, 2004; Penney, Marshall, \& Simpson, 2016; Philipse, Koeter, van der Staak, \& van den Brink, 2006). Approximately $70 \%$ of staff report having been assaulted by patients at some point during the previous 12 months (Kelly, Subica, Fulginiti, Brekke, \& Novaco, 2015). Most individuals in Canadian forensic psychiatric populations have been found not criminally responsible on account of mental disorder (NCRMD), which is a designation reserved for individuals with severe mental illnesses (most often psychotic spectrum disorders; Crocker et al., 2015) who cannot be held responsible for their crimes.

Much of the research examining adverse events in this population has focused on what might be called "proximal" risk factors (see Sedgwick, Young, Das, \& Kumari, 2016 for a review on risk factors for adverse events in forensic psychiatric populations). Proximal risk factors are those that occur closer in time (i.e., are proximal) to the behaviour of interest (Day \& Weisner, 2019). However, while some proximal factors, including previous psychiatric admissions, have been consistently found to predict inpatient violence, less is known about the continuity of behaviour throughout the lifespan, and about what might be called "distal" risk factors (Sedgwick et al., 2016). Distal risk factors are those that occur farther away in time (i.e., are distal) to the behaviour of interest (Day \& Weisner, 2019). For example, these might include factors that are present in childhood. This thesis sought to answer whether forensic psychiatric 
patients who experience adverse outcomes in adulthood, are those who experienced risk factors in childhood. A developmental approach to studying outcomes in adulthood is important because it allows for better understanding of the effects of early developmental variables on events later in life, across the lifespan. Before causal links can be identified between childhood risk factors and adult behaviour (which would allow for the development of early intervention and prevention programs), associations between childhood risk factors and adverse events in forensic psychiatric populations must first be identified. Only a small number of studies have examined whether childhood risk factors predict adverse events in forensic psychiatric populations. Using a developmental risk factor research (RFR) framework, a retrospective file review was conducted, which sought to understand whether childhood variables that have been found to predict criminal offending in adulthood also predict a variety of adverse events in forensic patients.

The following literature review contains five sections. The first section describes the characteristics of forensic psychiatric populations in Canada. Information on the most prevalent diagnoses and index offences is provided, followed by a typology for understanding violent offending in individuals with schizophrenia. The second section explains the developmental RFR framework, covering findings from notable longitudinal studies examining childhood risk factors for subsequent criminal offending. The third section examines childhood risk factors for offending in individuals with severe mental illnesses. The fourth section covers the prevalence of various adverse events that have been studied in forensic psychiatric populations, both while in hospital and after discharge to outpatient status. The fifth section describes the small body of research examining childhood predictors of adverse events in forensic psychiatric samples. A review of childhood predictors of inpatient violence in psychiatric populations is included in the sixth section, covering studies where the majority of patients had a severe mental illness. This 
section is included to supplement the small body of research in forensic psychiatric populations and to explore childhood risk factors for adverse events in individuals with severe mental illnesses.

\section{NCRMD Population}

In Canada, forensic psychiatric populations include individuals with severe mental illnesses who have been found not criminally responsible on account of mental disorder (NCRMD). According to Section 16 of the Canadian Criminal Code (Criminal Code, 1985), individuals can be found NCRMD if they commit an offense while suffering from a mental disorder that prevented them from being able to understand what they were doing at the time of the incident and that it was wrong. The most common primary diagnoses in this population are schizophrenia spectrum and other psychotic disorders (Crocker et al., 2015). According to the Diagnostic and Statistical Manual, Fifth Edition (DSM-5), these disorders are characterized by delusions (i.e., rigid beliefs that are not amenable to change, even when presented with disconfirming evidence), hallucinations (i.e., perceptual experiences in the absence of a stimulus), disorganized speech, thinking, or motor behaviour, and negative symptoms (i.e., the absence of behaviours that are considered common in the general population, such as significantly decreased speech output), and they include schizophrenia, schizophreniform disorder, schizoaffective disorder, and several other disorders (American Psychiatric Association, 2013).

An individual in Canada can be found NCRMD for both summary and indictable offences, yet the majority of individuals in forensic psychiatric hospitals have committed violent offences or offences against another person, such as assaults. Penney et al. (2016) found that $82.8 \%$ of individuals in their sample of individuals in forensic psychiatric hospitals in Ontario 
had a violent index offence, with assaults (23.0\%) and assaults causing bodily harm (28.7\%) being the most common. A larger study, with a sample of 1800 NCRMD patients across Ontario, Quebec, and British Columbia obtained similar estimates. Crocker et al. (2015) noted that 64.9\% of index offences for individuals found NCRMD were against another person, $16.9 \%$ were property offences, and $18.2 \%$ were other offences. The most common offences were assaults (26.5\%) and threats or other offences against a person (27.4\%; Crocker et al., 2015).

Hodgins (2008) identified three types of violent offenders among individuals with schizophrenia. The largest group of violent offenders with schizophrenia do not have a history of violent behaviour prior to the onset of illness but continue to exhibit aggressive behaviour toward others after illness onset. Another, smaller, group of offenders with schizophrenia have a history of antisocial behaviour that began in childhood or adolescence and persists into adulthood. Finally, a small group of individuals have no history of violent behaviour prior to illness onset, or around onset, until their thirties or forties when they engage in serious violence. This typology conceptualizes violent offending in individuals with schizophrenia, and outlines three distinct groups of offenders with schizophrenia, which are distinguished based on the age of onset of antisocial behaviour. However, it is not known whether the continuity of antisocial behaviour from childhood to adulthood in individuals found NCRMD can predict various adverse events while inpatient and after discharge that are common in this population.

\section{Developmental Risk Factor Research and Criminal Offending}

Developmental criminology focuses on the development of criminal and antisocial behaviour from birth and elucidates risk and protective factors that predict engaging in or abstaining from such behaviour at different points in the lifespan (Farrington, 2017). A review of several notable longitudinal studies that have significantly increased our understanding of 
protective factors and risk factors for engaging in criminal or antisocial behaviour and the course of this behaviour follows. The design of these studies allows for establishing a timeline for events, experiences, and the onset of behaviours or illnesses (Farrington, 2017). However, there are some criticisms of the RFR approach for studying criminality. Most research in this field has focused on males, due to the low prevalence of criminal and antisocial behaviour in females. Since the majority of research has consisted of only male samples, it is not known whether the same childhood risk factors predict offending in both males and females. There is some evidence from small samples of persistent female offenders that childhood risk factors that predict offending are similar but not identical to those that predict offending in males (Moffitt \& Caspi, 2001).

Several longitudinal studies have shown that individuals who offend in adulthood are significantly different from individuals who do not offend in adulthood on several childhood risk factors (Bergman \& Andershed, 2009; Farrington, Jolliffe, Loeber, Stouthamer-loeber, \& Kalb, 2001; Moffitt \& Caspi, 2001; Smith \& Thornberry, 1995). Cross-sectional studies have also noted similar findings (Reavis, Looman, Franco, \& Rojas, 2013; Ward et al., 2010). For example, using longitudinal data from the Dunedin cohort, Moffitt and Caspi (2001) found that for 20 out of 26 childhood risk factor measures, males who had a childhood history of aggressive or delinquent behaviour which continued into young adulthood (life-course persistent path) scored significantly higher than males who had an onset and desistence of delinquent behaviour in adolescence (adolescent-limited path). Similarly, life-course persistent path females scored higher on most risk factor measures compared to adolescent-limited path females. Farrington (2015) identified six risk factor categories for offending that have come out of longitudinal risk factor research: individual factors, parental factors, child-rearing factors, peer factors, school 
factors, and neighbourhood factors. Some other longitudinal work has also identified childhood trauma (such as physical and sexual abuse) as a risk factor for later offending (Reavis et al., 2013; Smith \& Thornberry, 1995).

Due to the unavailability of information on child-rearing factors, peer factors, school environment factors, and neighbourhood factors in patient files, the current study will focus on risk factor information that is available in clinical files. Thus, a literature review of longitudinal and cross-sectional studies examining individual factors, family factors, school achievement factors and trauma history follows. Individual factors include, but are not limited to, factors such as hyperactivity and antisocial behaviour in childhood, family factors include parental criminal or psychiatric history, school factors include low achievement and abilities, and childhood trauma includes experiences of physical or sexual abuse.

Individual factors. In terms of individual factors, longitudinal studies have found that IQ and school achievement, hyperactivity, and antisocial behaviour are predictors of offending in adulthood (Bergman \& Andershed, 2009; Moffitt \& Caspi, 2001). Moffitt and Caspi (2001) found that life-course persistent path males had significantly lower IQ, memory, reading abilities, and more aggressive and hyperactive behaviour than adolescent-limited path males. Bergman and Andershed (2009) found that men who began offending before age 21 and continued into adulthood had lower school grades and verbal ability, and higher aggression, hyperactivity, and alcohol abuse before age 18 than a non-offender group.

Family factors. Several family factors have been linked to criminal offending. In a crosssectional study, Reavis et al. (2013) found that rates household substance abuse, household mental illness, domestic violence perpetrated by the father, and criminal behaviour in the household were significantly higher among a sample of male offenders, compared to a normative 
sample. In terms of parental criminality, arrests of the father have been found to predict delinquency in boys (Farrington et al., 2001), and presence of criminal family members in adolescence increases the likelihood that offenders belong to moderate-rate or high-rate offending groups, than those who do not have criminal family members, when compared to a low-rate offender group (Ward et al., 2010). Furthermore, parental psychopathology predicts persistent offending. Moffitt and Caspi (2001) found that life-course persistent path males were more likely to have a mother with mental health issues than adolescent-limited path males, and Reavis et al. (2013) noted that rates of mental illness in the household were significantly higher among an offender group, compared to a normative sample.

Coming from a broken home and involvement with alternative care have also been linked to high-rate offending (Ward et al., 2010). Specifically, offenders who experienced a broken home, or were involved with alternative care in childhood, were more likely to belong to moderate-rate and high-rate offender groups, respectively, than those who did not experience a broken home or were not involved with alternative care, when compared to low-rate offenders. Similarly, offenders who were involved with alternative care in adolescence were more likely to belong to high-rate offender groups than those who were not involved in alternative care, when compared to the low-rate offender group.

Trauma factors. Finally, experiences of childhood abuse have been implicated in offending. Rates of psychological, physical, and sexual abuse are significantly higher among offenders when compared to a normative sample (Reavis et al., 2013). Furthermore, experiences of childhood maltreatment significantly predict subsequent adolescent delinquency, as measured by official criminal records (Smith \& Thornberry, 1995). 
While all these risk factors have been linked to criminal offending, and particularly persistent offending, it is unclear how these factors are associated with adverse events in a forensic psychiatric population.

\section{Severe Mental Illnesses and Criminal Offending}

Research has shown that individuals with severe mental illnesses, particularly schizophrenia, are at an increased risk of arrest for a violent offence compared to individuals without a mental illness (Brennan, Mednick, \& Hodgins, 2000). Even when marital status, socioeconomic status, and comorbid personality disorders and substance abuse are controlled for, men and women with schizophrenia are still at an elevated risk of being arrested for a violent crime (Brennan et al., 2000). Several studies have found an association between conduct disorder in childhood and schizophrenia in adulthood (Hodgins, Cree, Alderton, \& Mak, 2008; KimCohen et al., 2003; Robins \& Price, 1991). Hodgins et al. (2008) found that adults with schizophrenia who had a childhood diagnosis of conduct disorder engaged in higher rates of selfreported assaults and had more criminal convictions than adults with schizophrenia who did not have a diagnosis of conduct disorder in childhood. A study examining risk factors for crime among individuals with schizophrenia found that parental violent crime was associated with violent crime for both men and women with schizophrenia (Fazel, Grann, Carlström, Lichtenstein, \& Långström, 2009). Another study with a sample of inpatient and outpatient men with schizophrenia found that witnessing domestic violence in childhood was associated with increased violence in adulthood (Oakley, Harris, Fahy, Murphy, \& Picchioni, 2016). However, little is known about how these and other childhood variables impact institutional and community behaviour and whether these same risk factors can predict behaviour while in hospital and after discharge in an NCRMD population. 


\section{Adverse Events in Forensic Psychiatric Populations}

Official criminal recidivism is the most often studied outcome in forensic psychiatric populations (Sedgwick et al., 2016). Estimates of the prevalence of recidivism among individuals found NCRMD vary yet are consistently lower than recidivism in general criminal populations. The prevalence of recidivism across three cohorts of Canadian federal offenders followed for two years after release was approximately $40 \%$, while the prevalence of violent recidivism was 13\% (Bonta, Rugge, \& Dauvergne, 2003). In contrast, studies examining rates of recidivism in forensic psychiatric populations have arrived at lower prevalence estimates. Charette et al. (2015) followed 1800 NCRMD patients across Ontario, Quebec, and British Columbia for 3 years post-discharge from the hospital, and found that $17 \%$ of individuals were convicted of any offence within that 3-year period. Coid et al. (2007) followed men and women for a mean of 6.2 years after discharge from forensic psychiatric hospitals in England and Wales and found that the prevalence of recidivism for men was $34.3 \%$, and $15.3 \%$ for women. In terms of violent recidivism, $18.1 \%$ of men and $5.1 \%$ of women were convicted of a violent offence during follow-up (Coid et al., 2007). Another study found that $6 \%$ of former patients were convicted for a violent offense after a follow up period of 1 year, and 31\% after 11 years (De Vries Robbé et al., 2015), while Penney et al. (2016) found that no one in their sample had been officially convicted 12 months after discharge. While official criminal recidivism is an important outcome to study in all offender populations, those found NCRMD have low rates of recidivism, especially over the span of 12 months, and other types of outcomes might be more common in this population and deserving of further attention.

Inpatient violence is a prevalent and concerning issue in forensic psychiatric populations. Estimates of the rates of inpatient violence vary. Hoptman et al. (1999) found that 33\% of 
patients committed an assault within the first three months of hospitalization. However, Linhorst and Scott (2004) noted a smaller prevalence of physical assaults. They found that $21 \%$ of patients physically assaulted others during the year prior to the study date (Linhorst \& Scott, 2004). Broderick et al. (2015) followed patients for 3 years and found that $31 \%$ engaged in physical violence toward staff or other patients. Inpatient violence rarely results in a criminal conviction, yet it may be indicative of a propensity to continue engaging in antisocial behaviour after the onset of offending.

Similarly, Penney et al. (2016) found that $23 \%$ of patients had engaged in violence after discharge, which included assaulting or threatening another person, over a 12 month period. Penney et al. (2016) examined several additional adverse events for a period of 12 months after discharge in a sample of 87 forensic patients who were found NCRMD. Although no patients were formally reconvicted during the 12 month study period, there were high rates of victimization (29\%), treatment non-compliance during the follow-up period (61\%), and hospital readmission (28\%; Penney et al., 2016). The authors found that scores on the Historical, Clinical, and Risk Management violence risk assessment (HCR-20V3; Douglas, Hart, Webster, \& Belfrage, 2013), a measure of static and dynamic risk factors, predicted certain adverse events. Specifically, when controlling for static risk factors (i.e., risk factors that are historical in nature and thus not amenable to change), changes in dynamic risk factors (i.e., those that can change over time, such as severity of mental illness symptoms) predicted violence and re-admission to hospital. Thus, the research by Penney et al. (2016) shows that there are other important outcomes to examine in forensic psychiatric populations beyond violence and recidivism. 


\section{Childhood Predictors of Outcomes in Forensic Psychiatric Populations}

Most research examining childhood risk factors for outcomes in forensic psychiatric populations has focused on recidivism and inpatient violence. While there are other potential outcomes to consider, such as treatment compliance, absconding, and readmission to hospital, little is known about which childhood variables predict those. A recent systematic review by Sedgwick et al. (2016) examining predictors of various outcomes in forensic psychiatric populations found that very few studies examined childhood predictors of adverse events, so the authors could not draw any conclusions regarding the findings. Furthermore, what little research there is was conducted over 10 years ago, and it is important to study childhood predictors for outcomes in NCRMD populations today, to see if the findings still hold. Nonetheless, a review of the few available studies examining childhood risk factors for outcomes in forensic psychiatric populations follows.

Using a sample of 183 male forensic psychiatric patients at a maximum security hospital in New York City, Hoptman et al. (1999) conducted a study to assess which variables differed between patients who engaged in assaultive behaviour while in the facility and those who did not. The sample included individuals who were hospitalized in order to receive treatment to restore fitness to stand trial $(84.7 \%)$, individuals who were admitted after a verdict of not guilty due to mental disorder $(8.7 \%)$, and those who had received emergency transfers from a civic hospital (6.6\%). The most common diagnoses were schizophrenia (58\%) and substance abuse or dependence $(57 \%)$ and $31 \%$ of the sample had both diagnoses. The authors assessed childhood variables, including physical and sexual abuse, neglect, and a parent who engaged in intravenous drug use or alcohol abuse or who had a history of psychiatric hospitalizations. After the first three months of hospitalization, 33\% of patients committed assault, which was defined as any 
violent incident initiated by the patient. They found that the assaultive and non-assaultive groups did not differ on any childhood or family environment variables other than childhood physical abuse. A history of childhood physical abuse was more common among patients who had committed assault while in hospital than among those who did not commit an assault while in hospital (Hoptman et al., 1999).

In a study conducted 25 years ago, Harris et al. (1993) examined the set of variables that predict violent recidivism in two samples of offenders. The first sample included 332 men who had previously been admitted to a maximum security forensic psychiatric institution, and the second sample included 286 men who had been admitted briefly for a psychiatric assessment prior to trial. One third of their entire sample had been acquitted due to insanity (which was the term used prior to NCRMD in Canada) with the majority diagnosed with a personality disorder. Those who violently recidivated significantly differed from those who did not on a number of childhood history variables. Individuals who violently recidivated completed fewer years of schooling, had greater elementary school maladjustment, more childhood aggression, and more childhood behaviour problems. A greater percentage of individuals who violently recidivated were suspended or expelled from school, were arrested under the age of 16, and were separated from their parents prior to age 16. Individuals who violently recidivated and those who did not, did not differ on adolescent alcohol abuse, socioeconomic status as children or parental crime, psychiatric history, or alcoholism.

Using these findings, the authors created an instrument to predict violent recidivism - the Violence Risk Appraisal Guide (VRAG). They conducted a stepwise discriminant analysis to reduce the number of predictors. They identified 12 variables for inclusion. Two childhood variables were identified for inclusion and they both had small correlations with violent 
recidivism (note: all identified predictors had small correlations with violent recidivism, not just the childhood variables). These variables were separation from parents under the age of 16 ( $r=$ $.25, p<.05)$, and elementary school maladjustment $(r=.30, p<.05$; Harris et al., 1993). While this important work by Harris and colleagues contributed to the development of the VRAG, it is not known whether these developmental items may also predict other adverse events in forensic psychiatric populations. Furthermore, it is also not known if these findings can apply to NCRMD populations in Canada today, as the majority of individuals have a psychotic disorder, whereas most individuals in the sample examined in Harris et al. (1993) were diagnosed with a personality disorder.

Philipse et al. (2006) examined predictors of criminal recidivism in a sample of 132 forensic psychiatric patients (92.4\% male) from seven hospitals in The Netherlands. In terms of diagnoses, 33.3\% of the sample had at least one personality disorder, and $69.7 \%$ had a DSM-III or DSM-III-R axis I diagnosis. Disorders with psychotic symptoms were the most common primary axis I diagnosis (29.6\%). The authors examined the ability of static and dynamic factors to predict recidivism in this sample. Static factors refer to historical factors that are not amenable to change, whereas dynamic factors are those that are malleable and can be changed. Among the static variables, the authors included childhood history items from two widely used risk assessments, the HCR-20 (Webster, Douglas, Eaves, \& Hart, 1997) and the VRAG (Harris et al., 1993).

They assessed the age at first conviction (which is similar to the HCR-20 item that assesses "young age at first violent incident") and the number of institutional homes the patient resided in before turning 17 (which is related to the HCR-20 item that assesses "early maladjustment" and the VRAG item, "lived with both biological parents to age 16"). Dynamic 
factors included patient behaviour and clinical symptoms, among others. The authors conducted a Cox regression analysis, which eliminated redundant predictors in the model. The final model included only static factors yet did not include the childhood history items. Factors retained in the final model that increased the risk of reoffending were number of times the patient was absent without permission, personality disorder and substance use comorbidity, and a diagnosis of a cluster B personality disorder at the time of admission. The last factor, diagnosis of psychosis at the time of admission, decreased the risk of reoffending. Thus, Philipse et al. (2006) did not find that the childhood history variables included in their model added significant predictive validity (Philipse et al., 2006).

\section{Childhood Predictors of Outcomes in Psychiatric Populations}

Some additional research has examined childhood predictors of adverse events in psychiatric populations of individuals with severe mental illnesses, including schizophrenia. Blomhoff et al. (1990) examined which variables predicted violence in sample of individuals admitted to a psychiatric emergency ward. The majority of their sample had either schizophrenia or a major affective disorder (including bipolar disorders and depressive disorders). The remainder of the patients had organic psychosis, brief reactive psychosis, or a nonpsychotic disorder. They compared a group of 25 psychiatric patients who had been violent while in hospital with 34 patients who had not been violent. The authors defined violence as an act of physical aggression toward another person. They did not examine verbal aggression. The childhood history variables assessed were violence in the family (most often between parents) and being identified as a "problem child" (e.g., being frequently absent from or dropping out of school, requiring psychiatric treatment). The authors found that patients who had engaged in physical aggression had significantly more violence in their family environment as children, and 
this was the only significant difference between groups on demographic variables. However, no variables improved prediction above and beyond previous violence by the patient, which they found correctly classified $80 \%$ of patients in their sample (Blomhoff et al., 1990).

Krakowski, Convit, Jaeger, Shang, and Volavka (1989) examined historical variables, among others, of individuals with schizophrenia in an inpatient hospital unit to assess whether there were differences among those who engaged in violent behaviour and those who had not. They separated their sample into three groups: 1) those who were not violent $(n=34)$; 2$)$ those who engaged in infrequent violent behaviour $(n=27)$; and 3) those who engaged in frequent violent behaviour $(n=28)$. Historical childhood variables included parental substance abuse or psychiatric hospitalization, stability of living arrangements and relationship with father, and history of physical abuse. The authors hypothesized that the patients who were more frequently violent would have had more negative experiences in their early environments. However, they did not find that the three groups differed on any childhood history variables (Krakowski et al., 1989).

Bruce and Laporte (2015) examined whether early behavioural problems (signified by a diagnosis of conduct disorder [CD] before age 12) would explain the link between childhood traumatic exposure and risk of violent behaviour in a sample of 162 men with severe mental illnesses in hospital. Severe mental illnesses were defined as schizophrenia and related disorders and major mood disorders. The majority of the patients in their sample were diagnosed with schizophrenia (58.6\%), and the remaining had diagnoses of schizoaffective disorder, bipolar disorder, and other severe mental illnesses. Patients were separated into 3 groups: 1) those who met criteria for CD as children and criteria for antisocial personality disorder (ASPD) as adults; 2) those who did not meet criteria for CD as children, but met criteria for ASPD as adults; and 3) 
those who did not meet criteria for CD or ASPD. Traumatic events in childhood included being the victim of a crime, experiencing a natural disaster, or physical or sexual abuse. The authors coded self-reported aggressive and assaultive behaviour over the preceding six months, and found that patients who had met criteria for CD as children and ASPD as adults had significantly greater percentages of violent acts within the preceding six months, and of childhood trauma compared to both the group who did not meet criteria for CD but met criteria for ASPD, and the group who did not meet criteria for CD or ASPD. In all, they found that the patients who had experienced childhood trauma had greater odds of engaging in violent acts, and that this relationship was explained by early behavioural problems signified by a diagnosis of $\mathrm{CD}$. The authors noted that these findings illustrate the need to develop intervention programs for children who have experienced trauma and meet criteria for CD (Bruce \& Laporte, 2015).

\section{Limitations of Past Research}

No research to date has comprehensively examined whether childhood risk factors can predict inpatient behaviour in an NCRMD population. The majority of studies have examined only a small number of childhood risk factors. Furthermore, only few studies have examined a wider variety of outcomes (e.g., Penney et al., 2016), while no studies, to the best of my knowledge, have examined the prevalence of positive outcomes in these populations, such as gaining employment.

Previous research has had mixed findings regarding whether childhood risk factors can predict adverse events among forensic psychiatric and psychiatric populations. While some research has found that childhood risk factors predict adverse events (Bruce \& Laporte, 2015; Harris et al., 1993), other work has not (Blomhoff et al., 1990; Krakowski et al., 1989; Philipse et al., 2006). However, no firm conclusion can be made, as these studies did not examine the same 
childhood risk factors or adverse events, and the populations studied varied in terms of diagnoses and criminal histories.

\section{The Current Thesis Project}

This study examined whether childhood risk factors can predict adverse events in a forensic psychiatric population of individuals found NCRMD at a forensic psychiatric hospital in Southwestern Ontario. Due to a lack of sufficient research and mixed findings, this project is exploratory in nature.

My research will address the following questions:

1. What is the prevalence of various adverse events in a forensic psychiatric population?

a. Does the prevalence of adverse events differ between male and female patients?

2. Which developmental risk factors predict adverse events in an NCRMD population? Hypothesis: Both childhood and adolescent risk factors will predict adverse events in an NCRMD population

3. Do risk factors in adolescence better predict adverse events than risk factors in childhood?

Hypothesis: Adolescent risk factors will better predict adverse events than childhood risk factors.

4. Do developmental risk factors still predict adverse events in an NCRMD population when total score on the HCR-20 is controlled for?

5. Do male and female patients differ on developmental predictors of adverse events? 


\section{Methods}

\section{Design and Rationale}

A retrospective file review of 150 files of forensic psychiatric patients found NCRMD at a forensic psychiatric hospital in Southwestern Ontario was conducted in order to identify whether risk factors in childhood and adolescence predict adverse events in inpatients and outpatients.

\section{Sample Characteristics}

Patient files of a sample of individuals found NCRMD at a forensic psychiatric hospital in South Central Ontario were examined. Of a possible 169 files, 150 were coded. Files were coded until a final sample of 150 males $(n=100)$ and females $(n=50)$ was achieved. Patient files were selected from the patient list in the forensic patient database in chronological order, beginning from those most recently found NCRMD. Dates of NCRMD findings spanned from 2004 to 2012. Women were over-sampled; thus, the range for date of NCRMD finding spans more years for women (2004 - 2012, compared to 2009 - 2012 for men). In terms of patient location at the time of the report used for coding, $53.3 \%$ of patients were on an inpatient unit, 42.7\% were outpatients, $0.7 \%$ were AWOL, and the location was missing for $3.3 \%$ of patients.

Developmental information was gathered from Ontario Review Board (ORB) hospital reports. Nineteen files were excluded due to not having enough developmental information in the ORB hospital report $(n=9)$, missing the ORB hospital report $(n=7)$, or restricted file access $(n$ $=3$ ). A report was deemed to have insufficient developmental information if the developmental section was too short (i.e., a few sentences), such that less than $80 \%$ of the coding form could be completed. These files were excluded on the assumption that the writer of the report could not 
gather sufficient information about the patient's childhood and adolescence through interviews or official records, thus was unable to comment on the patient's history.

Excluded patients were compared to patients in the sample on presence of adverse events, to assess whether those who were excluded were more likely to experience an adverse event. Excluded patients were not more likely to experience an adverse event than patients included in analyses, $X^{2}(1, \mathrm{~N}=169)=0.311, p>.05$.

Descriptive statistics were calculated to assess whether there were differences in criminal or clinical variables between patients who experienced an adverse event and those who did not. T-tests or Mann-Whitney U tests were done for continuous and count variables. Patients who experienced an adverse event $(M=25.6, S D=10.0)$ were significantly younger at the time of their first arrest or charge than patients who did not experience an adverse event $(M=33.4, S D=$ $16.3), t(139)=2.947, p<.05$, and those who experienced an adverse event $(M=34.2, S D=$ 10.4) were significantly younger at the time of the index event than those who did not experience an adverse event $(M=39.9, S D=14.3), t(150)=2.463, p<.05$. Furthermore, patients who experienced an adverse event had a higher score on the HCR-20 $(M=23.7, S D=5.6)$ than patients who did not experience an adverse event $(M=15.2, S D=4.8)$ during the coded clinical year $t(150)=-9.155, p<.05$. Patients who experienced an adverse event also had a greater number of previous charges, Mann-Whitney $U=991.0, n_{1}=40, n_{2}=75, p<.05$, and convictions Mann-Whitney $U=1590.0, n_{1}=45, n_{2}=92, p<.05$, but not a greater number of index offences Mann-Whitney $U=2176.0, n_{1}=48 n_{2}=102, p=.262$, than those who did not experience an adverse event. Table 1 presents differences between those who had an adverse event and those who did not on index offence type and diagnosis. 
Table 1

Criminal and Clinical Characteristics Comparing those who Experienced an Adverse Event and Those who did Not

\begin{tabular}{|c|c|c|c|c|c|}
\hline & $\begin{array}{c}\text { Combined } \\
\text { sample }(\mathrm{n}=150) \\
\text { Frequency } \\
\text { (Percent) }\end{array}$ & $\begin{array}{c}\text { Adverse Event } \\
(\mathrm{n}=102)\end{array}$ & $\begin{array}{c}\text { No Adverse } \\
\text { Event }(\mathrm{n}=48) \\
\text { Frequency } \\
\text { (Percent) }\end{array}$ & $X^{2}$ & $\phi$ \\
\hline \multicolumn{6}{|l|}{ Index offence } \\
\hline Violent & $124(83 \%)$ & $79(77 \%)$ & $45(94 \%)$ & $6.051 *$ & $-.201 *$ \\
\hline Non-violent & $65(43 \%)$ & $51(50 \%)$ & $14(29 \%)$ & $5.769 *$ & $.196^{*}$ \\
\hline Sexual & $16(11 \%)$ & $12(12 \%)$ & $4(8 \%)$ & 0.403 & .052 \\
\hline \multicolumn{6}{|l|}{ Diagnosis } \\
\hline Schizophrenia & $97(65 \%)$ & $71(70 \%)$ & $26(54 \%)$ & 3.406 & .151 \\
\hline $\begin{array}{l}\text { Delusional } \\
\text { disorder }\end{array}$ & $7(5 \%)$ & $4(4 \%)$ & $3(6 \%)$ & 0.398 & -.051 \\
\hline $\begin{array}{l}\text { Schizoaffective } \\
\text { disorder }\end{array}$ & $19(13 \%)$ & $12(12 \%)$ & $7(15 \%)$ & 0.234 & -.040 \\
\hline Bipolar disorder & $7(5 \%)$ & $2(2 \%)$ & $5(10 \%)$ & $5.246^{*}$ & $-.187 *$ \\
\hline Other psychotic & $8(5 \%)$ & $6(6 \%)$ & $2(4 \%)$ & 0.190 & .036 \\
\hline $\begin{array}{l}\text { Major } \\
\text { depressive } \\
\text { disorder }\end{array}$ & $5(3 \%)$ & $2(2 \%)$ & $3(6 \%)$ & 1.864 & -.111 \\
\hline $\begin{array}{l}\text { Intellectual } \\
\text { disability }\end{array}$ & $9(6 \%)$ & $9(9 \%)$ & $0(0 \%)$ & $4.506^{*}$ & .137 \\
\hline $\begin{array}{l}\text { Personality } \\
\text { disorder }\end{array}$ & $29(19 \%)$ & $23(23 \%)$ & $6(13 \%)$ & 2.113 & .119 \\
\hline $\begin{array}{l}\text { Substance use } \\
\text { disorder }\end{array}$ & $82(55 \%)$ & $59(58 \%)$ & $23(48 \%)$ & 1.298 & .093 \\
\hline $\begin{array}{l}\text { Paraphilic } \\
\text { disorder }\end{array}$ & $4(3 \%)$ & $3(3 \%)$ & $1(2 \%)$ & 0.093 & .025 \\
\hline
\end{tabular}

Descriptive statistics were also calculated to assess whether there were differences in demographic, criminogenic, or clinical variables between male and female patients. Male and female patients differed on several demographic variables. Male patients $(M=26.2, S D=12.0)$ were significantly younger than female patients $(M=32.2, S D=13.9)$ at the time of their first 
Table 2

Criminal and Clinical Characteristics for Combined Sample and Comparing Males and Females

\begin{tabular}{|c|c|c|c|c|c|}
\hline & $\begin{array}{c}\text { Combined } \\
\text { sample }(n=150)\end{array}$ & $\begin{array}{c}\text { Males } \\
(\mathrm{n}=100)\end{array}$ & $\begin{array}{c}\text { Females } \\
(\mathrm{n}=50)\end{array}$ & \multirow{2}{*}{$X^{2}$} & \multirow{2}{*}{$\phi$} \\
\hline & $\begin{array}{c}\text { Frequency } \\
\text { (Percent) }\end{array}$ & $\begin{array}{l}\text { Frequency } \\
\text { (Percent) }\end{array}$ & $\begin{array}{l}\text { Frequency } \\
\text { (Percent) }\end{array}$ & & \\
\hline \multicolumn{6}{|l|}{ Index offence } \\
\hline Violent & $124(83 \%)$ & $83(83 \%)$ & $41(82 \%)$ & 0.023 & -.012 \\
\hline Non-violent & $65(43 \%)$ & $42(42 \%)$ & $23(46 \%)$ & 0.217 & .038 \\
\hline Sexual & $16(11 \%)$ & $15(15 \%)$ & $1(2 \%)$ & $5.912 *$ & $-.199 *$ \\
\hline \multicolumn{6}{|l|}{ Diagnosis } \\
\hline Schizophrenia & $97(65 \%)$ & $71(71 \%)$ & $26(52 \%)$ & $5.266^{*}$ & $-.187 *$ \\
\hline $\begin{array}{l}\text { Delusional } \\
\text { disorder }\end{array}$ & $7(5 \%)$ & $2(2 \%)$ & $5(10 \%)$ & $4.795^{*}$ & $.179 *$ \\
\hline $\begin{array}{l}\text { Schizoaffective } \\
\text { disorder }\end{array}$ & $19(13 \%)$ & $8(8 \%)$ & $11(22 \%)$ & $5.906^{*}$ & $.198 *$ \\
\hline Bipolar disorder & $7(5 \%)$ & $5(5 \%)$ & $2(4 \%)$ & 0.075 & -.022 \\
\hline Other psychotic & $8(5 \%)$ & $5(5 \%)$ & $3(6 \%)$ & 0.066 & .021 \\
\hline $\begin{array}{l}\text { Major } \\
\text { depressive } \\
\text { disorder }\end{array}$ & $5(3 \%)$ & $2(2 \%)$ & $3(6 \%)$ & 1.655 & .105 \\
\hline $\begin{array}{l}\text { Intellectual } \\
\text { disability }\end{array}$ & $9(6 \%)$ & $7(7 \%)$ & $2(4 \%)$ & 0.532 & -.060 \\
\hline $\begin{array}{l}\text { Personality } \\
\text { disorder }\end{array}$ & $29(19 \%)$ & $20(20 \%)$ & $9(18 \%)$ & 0.085 & -.024 \\
\hline $\begin{array}{l}\text { Substance use } \\
\text { disorder }\end{array}$ & $82(55 \%)$ & $66(66 \%)$ & $16(32 \%)$ & $15.55^{*}$ & $-.322 *$ \\
\hline $\begin{array}{l}\text { Paraphilic } \\
\text { disorder }\end{array}$ & $4(3 \%)$ & $4(4 \%)$ & $0(0 \%)$ & 2.055 & -.117 \\
\hline
\end{tabular}

arrest or charge, $t(139)=-2.64, p<.009$. Male $(M=35.3, S D=12.5)$ and female patients $(M=$ $37.4, S D=11.2)$ did not differ on age at index offence, $t(148)=-0.983, p>.05$. Male $(M=21.1$, $S D=6.0)$ and female $(M=20.6, S D=8.0)$ patients also did not differ on HCR-20 total scores $t(148)=.381, p>.05$. Male patients also had a greater number of previous charges, MannWhitney $U=1168.50, n_{1}=75, n_{2}=40, p<.05$, but not convictions, Mann-Whitney $U=1701, n_{1}$ 
$=91, n_{2}=46, p=.06$, or index offences, Mann-Whitney $U=2072, n_{1}=100, n_{2}=50, p=.08$.

Information regarding type of index offence and diagnosis is presented in Table 2. In summary, diagnoses of schizophrenia, delusional disorder, schizoaffective disorder, and substance use disorder differed by gender.

\section{Procedure}

This research was approved by the Ryerson University Research Ethics Board (REB). The creation of a large, de-identified forensic patient database for the ongoing forensic research program was already approved by the ethics committee at the forensic psychiatric hospital. Upon approval from Ryerson, an amendment was filed at the forensic psychiatric hospital to allow for the collection developmental risk factors, derived from patient files, for the purpose of adding these risk factors into the larger database. In the larger database, each patient was assigned a unique identification number. A separate, password protected, file contained patient names and their associated identification numbers. It was necessary to retain this file, as information collected for this thesis was obtained from patient files and added to the forensic patient database. For statistical analyses, only aggregated data were used.

\section{Materials}

Risk factors. Information regarding developmental risk factors was gathered from ORB hospital reports. These reports are prepared annually by a forensic psychiatrist at the forensic psychiatric hospital for individuals who have been found NCRMD and are part of a review process to determine whether there will be changes to an individual's conditions (e.g., transfer to lower or higher security, discharge into the community, etc.). For annual ORB reviews, course over the current clinical year is added to the report from the previous year. As such, historical and background information usually does not differ between iterations of the reports. However, for the purpose of this thesis, the most recent available report was used, in the event that any 
historical or background information happened to be updated. For the preparation of ORB hospital reports, developmental information is gathered using a standard psychiatric semistructured interview with the patient and family members conducted by a forensic mental health care professional, and collateral information is obtained from any available medical records or criminal records. As such, it could be reliably concluded that the absence of a mention of a developmental risk factor in a report, was indicative of an absence of the developmental risk factor. Unfortunately, developmental protective factors are not assessed during interview, thus were not available in reports; therefore, it was not possible to obtain information about protective factors from ORB hospital reports.

Using a risk factor research paradigm, developmental risk factors were coded, specifying age range of occurrence: childhood (ages 0-12) or adolescence (ages 13-18). Exact ages of onset were frequently not stated in the ORB hospital reports; thus, age of onset could not be recorded as a continuous variable. The coding form used for the present study was an adapted version of a coding scheme used in previous research in the Psychology of Crime and Delinquency Lab at Ryerson (Ward et al., 2010; See Appendix A for Developmental Risk Factor Coding Scheme).

Variables that were coded included individual factors, such as low intelligence or poor academic achievement, hyperactivity or inattention, antisocial behaviour, alcohol and/or drug use, trauma factors, such as experiencing sexual or physical abuse, and family factors, such as family criminality, parental psychiatric history, and involvement with alternative care, such as child welfare. Each risk factor included several options for indicating that the risk factor was present. For example, antisocial behaviour in childhood could be indicated by behaviours such as stealing, being physically aggressive, or running away from home, among others. If any indicator of a risk factor was present it was assigned a value of ' 1 ,' then corresponding the risk factor was 
coded as present and assigned a value of '1.' Absence of any mention of indicators of a risk factor was considered an absence of the risk factor and was assigned a value of ' 0 .'

Adverse events. Adult variables for forensic patients, such as diagnoses, index offense, adult criminal history, and adverse events that occurred over one clinical year (defined as the time between consecutive ORB reviews for each patient, which occur once a year) were previously coded for other research at the institution and entered into a database to be used for ongoing forensic research. For the purpose of this thesis, adverse events were obtained from the database. Adverse events consisted of behaviours and events that occurred either in the hospital or in the community. Events were coded as present (1) or absent (0). The database did not include information regarding the date of occurrence of the adverse event, or whether it occurred while the individual was an inpatient or outpatient. Adverse events included being placed in seclusion, restraint use, verbal or physical violence, suicide attempts, ideation, and self-harm, homicidal ideation or attempts, conflict with staff or patients, victimization, unauthorized absences, new charges under ORB, substance use relapses, any other breaches, and hospital readmission. Due to low base rates for most specific adverse events (refer to Table 5), adverse events were collapsed into one variable defined as the occurrence of any adverse event. Presence of any adverse event was assigned a value of ' 1 ' and absence of any adverse event a value of ' 0 .'

Interrater reliability. To assess the reliability of coding of risk factors, interrater reliability was computed using Cohen's Kappa (Cohen, 1960). All files used in final analyses were coded by the writer (coder 1). To assess for consistency in coding rules, a research assistant (coder 2) was trained to complete the developmental risk factor coding form and coded $20 \%$ of the files. In order to select these $20 \%$, the entire sample was sectioned off into groups of 5 (in order of coding by the first rater) and each file was numbered in order. Then, a random number 
between 1 and 5 was selected, and the corresponding file was included in the subsample to be coded by the second coder. This method was chosen, as the second coder was not available to code files at 2 time points to assess whether there was coding drift over time. Table 3 contains the Kappa values for childhood and adolescent risk factors. The average Kappa value for categories of childhood risk factors was .74, indicating good reliability. The average Kappa value for categories of adolescent risk factors was .64, indicating good reliability (Landis \& Koch, 1977).

Table 3

Inter-Rater Reliability for the Childhood and Adolescent Risk Factors.

\begin{tabular}{|c|c|c|c|c|c|}
\hline \multirow[b]{2}{*}{ Risk Factor } & \multicolumn{5}{|c|}{$\begin{array}{c}\text { Time } 1 \\
\text { (No. of cases: } 30) \\
\text { (No. of raters: 2) } \\
\end{array}$} \\
\hline & $\begin{array}{c}\text { Generalized } \\
\text { Kappa }\end{array}$ & $\begin{array}{c}\text { Level of } \\
\text { Agreement }^{\mathrm{a}}\end{array}$ & $\begin{array}{c}\% \text { Total } \\
\text { Agreement } \\
\text { (agreed on } \\
\text { cases } / 30 * 100)\end{array}$ & $\begin{array}{l}\text { Proportion of } \\
\text { Agreement } \\
\text { for "Yes" } \\
\text { (agreed/total) }\end{array}$ & $\begin{array}{l}\text { Proportion } \\
\text { of } \\
\text { Agreement } \\
\text { for "No" }\end{array}$ \\
\hline $\begin{array}{l}\text { Low intelligence or } \\
\text { poor academic } \\
\text { achievement in } \\
\text { childhood }\end{array}$ & $.57 *$ & Moderate & $73 \%$ & $4 / 8$ & $18 / 22$ \\
\hline $\begin{array}{l}\text { Low intelligence or } \\
\text { poor academic } \\
\text { achievement in } \\
\text { adolescence }\end{array}$ & $.68 *$ & Moderate & $73 \%$ & $13 / 17$ & $9 / 13$ \\
\hline Low intelligence & $--{ }^{b}$ & $--^{b}$ & $100 \%$ & $0 / 0$ & $30 / 30$ \\
\hline Learning disability & .65 & & $97 \%$ & $1 / 2$ & $28 / 29$ \\
\hline $\begin{array}{l}\text { Enrolled in special } \\
\text { education classes }\end{array}$ & 1.0 & Excellent & $100 \%$ & $1 / 1$ & $29 / 29$ \\
\hline $\begin{array}{l}\text { General academic- } \\
\text { related difficulties }\end{array}$ & .14 & Poor & $80 \%$ & $1 / 7$ & $23 / 29$ \\
\hline $\begin{array}{l}\text { Failed or repeated a } \\
\text { grade }\end{array}$ & .91 & Excellent & $97 \%$ & $7 / 8$ & $22 / 23$ \\
\hline
\end{tabular}


Table 3 continued

Inter-Rater Reliability for the Childhood and Adolescent Risk Factors.

\begin{tabular}{|c|c|c|c|c|c|}
\hline \multirow[b]{2}{*}{ Risk Factor } & \multicolumn{5}{|c|}{$\begin{array}{c}\text { Time } 1 \\
\text { (No. of cases: 30) } \\
\text { (No. of raters: 2) } \\
\end{array}$} \\
\hline & $\begin{array}{c}\text { Generalized } \\
\text { Kappa }\end{array}$ & $\begin{array}{c}\text { Level of } \\
\text { Agreement }^{\mathrm{a}}\end{array}$ & $\begin{array}{c}\% \text { Total } \\
\text { Agreement } \\
\text { (agreed on } \\
\text { cases } / 30 * 100)\end{array}$ & $\begin{array}{l}\text { Proportion of } \\
\text { Agreement } \\
\text { for "Yes" } \\
\text { (agreed/total) }\end{array}$ & $\begin{array}{l}\text { Proportion } \\
\quad \text { of } \\
\text { Agreement } \\
\text { for "No" }\end{array}$ \\
\hline $\begin{array}{l}\text { Dropped out of } \\
\text { school }\end{array}$ & .87 & Excellent & $93 \%$ & $14 / 16$ & $14 / 16$ \\
\hline $\begin{array}{l}\text { Problems at school in } \\
\text { childhood }\end{array}$ & $.65 *$ & Good & $95 \%$ & $1 / 2$ & $20 / 21$ \\
\hline $\begin{array}{l}\text { Problems at school in } \\
\text { adolescence }\end{array}$ & $1.0 *$ & Excellent & $100 \%$ & $6 / 6$ & $16 / 16$ \\
\hline $\begin{array}{l}\text { Lack of academic } \\
\text { motivation or } \\
\text { interest }\end{array}$ & .63 & Good & $93 \%$ & $2 / 4$ & $26 / 28$ \\
\hline Truant & .75 & Good & $90 \%$ & $7 / 10$ & $20 / 23$ \\
\hline Suspended & 1.0 & Excellent & $100 \%$ & $6 / 6$ & $24 / 24$ \\
\hline Expelled & .84 & Excellent & $97 \%$ & $3 / 5$ & $25 / 27$ \\
\hline $\begin{array}{l}\text { Hyperactivity- } \\
\text { impulsivity- } \\
\text { inattention in } \\
\text { childhood }\end{array}$ & $1.0 *$ & Excellent & $100 \%$ & $1 / 1$ & $23 / 23$ \\
\hline $\begin{array}{l}\text { Hyperactivity- } \\
\text { impulsivity- } \\
\text { inattention in } \\
\text { adolescence }\end{array}$ & -_b* & $--\mathbf{b}$ & $96 \%$ & $1 / 1$ & $23 / 24$ \\
\hline $\begin{array}{l}\text { Attention or } \\
\text { concentration } \\
\text { difficulties/easily } \\
\text { distracted }\end{array}$ & .62 & Good & $90 \%$ & $4 / 7$ & $23 / 26$ \\
\hline Restless & $--^{b}$ & $-{ }_{-}^{b}$ & $100 \%$ & $0 / 0$ & $30 / 30$ \\
\hline $\begin{array}{l}\text { Cannot wait or take } \\
\text { turns }\end{array}$ & $--{ }^{b}$ & $--^{b}$ & $100 \%$ & $0 / 0$ & $30 / 30$ \\
\hline $\begin{array}{l}\text { Hyperactive/very } \\
\text { active/energetic }\end{array}$ & .65 & Good & $97 \%$ & $1 / 2$ & $28 / 29$ \\
\hline $\begin{array}{l}\text { Difficulty planning } \\
\text { ahead }\end{array}$ & $--^{b}$ & $--^{b}$ & $100 \%$ & $0 / 0$ & $30 / 30$ \\
\hline $\begin{array}{l}\text { Attention-deficit } \\
\text { disorder diagnosis }\end{array}$ & $-{ }^{b}$ & $--^{b}$ & $100 \%$ & $0 / 0$ & $30 / 30$ \\
\hline
\end{tabular}


Table 3 continued

Inter-Rater Reliability for the Childhood and Adolescent Risk Factors.

\begin{tabular}{|c|c|c|c|c|c|}
\hline \multirow[b]{2}{*}{ Risk Factor } & \multicolumn{5}{|c|}{$\begin{array}{c}\text { Time } 1 \\
\text { (No. of cases: } 30 \text { ) } \\
\text { (No. of raters: } 2 \text { ) } \\
\end{array}$} \\
\hline & $\begin{array}{l}\text { Generalized } \\
\text { Kappa }\end{array}$ & $\begin{array}{c}\text { Level of } \\
\text { Agreement }^{\mathrm{a}}\end{array}$ & $\begin{array}{c}\% \text { Total } \\
\text { Agreement } \\
\text { (agreed on } \\
\text { cases } / 30 * 100)\end{array}$ & $\begin{array}{l}\text { Proportion of } \\
\text { Agreement } \\
\text { for "Yes" } \\
\text { (agreed/total) }\end{array}$ & $\begin{array}{l}\text { Proportion } \\
\quad \text { of } \\
\text { Agreement } \\
\text { for "No" }\end{array}$ \\
\hline $\begin{array}{l}\text { Attention- } \\
\text { deficit/hyperactivity } \\
\text { disorder diagnosis }\end{array}$ & 1.0 & Excellent & $100 \%$ & $1 / 1$ & $29 / 29$ \\
\hline $\begin{array}{l}\text { Antisocial behaviour in } \\
\text { childhood }\end{array}$ & .71 & Good & $87 \%$ & $8 / 12$ & $18 / 22$ \\
\hline $\begin{array}{l}\text { Antisocial behaviour in } \\
\text { adolescence }\end{array}$ & .51 & Moderate & $77 \%$ & $8 / 15$ & $15 / 22$ \\
\hline $\begin{array}{l}\text { Uses inappropriate } \\
\text { language }\end{array}$ & $--{ }^{b}$ & $--{ }^{b}$ & $100 \%$ & $0 / 0$ & $30 / 30$ \\
\hline \multicolumn{6}{|l|}{$\begin{array}{l}\text { Defiant toward set } \\
\text { rules or authority } \\
\text { figures }\end{array}$} \\
\hline Quick to anger & .78 & Good & $97 \%$ & $2 / 3$ & $27 / 28$ \\
\hline Temper tantrums & $--^{b}$ & $--\mathrm{b}$ & $100 \%$ & $0 / 0$ & $30 / 30$ \\
\hline Verbally aggressive & -.05 & Poor & $90 \%$ & $0 / 3$ & $27 / 30$ \\
\hline Physically aggressive & .58 & Moderate & $80 \%$ & $8 / 14$ & $16 / 22$ \\
\hline Sexually precocious & $.00^{\mathrm{c}}$ & $--^{c}$ & $97 \%$ & $0 / 1$ & $29 / 30$ \\
\hline $\begin{array}{l}\text { Engaged in } \\
\text { inappropriate } \\
\text { sexual behaviour }\end{array}$ & $.00^{\mathrm{c}}$ & $--^{c}$ & $93 \%$ & $0 / 2$ & $28 / 30$ \\
\hline Lying & .65 & Good & $97 \%$ & $1 / 2$ & $28 / 29$ \\
\hline Manipulative & $--^{b}$ & $--{ }^{b}$ & $100 \%$ & $0 / 0$ & $30 / 30$ \\
\hline Runs away & .63 & Good & $93 \%$ & $2 / 4$ & $26 / 28$ \\
\hline $\begin{array}{l}\text { Harmful towards } \\
\text { animals }\end{array}$ & $--{ }^{b}$ & $--^{b}$ & $100 \%$ & $0 / 0$ & $30 / 30$ \\
\hline Vandalized & 1.0 & Excellent & $100 \%$ & $1 / 1$ & $29 / 29$ \\
\hline Stealing & .44 & Moderate & $83 \%$ & $3 / 8$ & $22 / 27$ \\
\hline Break and enter & 1.0 & Excellent & $100 \%$ & $1 / 1$ & $29 / 29$ \\
\hline $\begin{array}{l}\text { Fire-setting } \\
\text { behaviour }\end{array}$ & 1.0 & Excellent & $100 \%$ & $1 / 1$ & $29 / 29$ \\
\hline Gang member & $--^{b}$ & $--{ }^{b}$ & $100 \%$ & $0 / 0$ & $30 / 30$ \\
\hline $\begin{array}{l}\text { Poor behaviour not } \\
\text { specified }\end{array}$ & $.00^{\mathrm{c}}$ & $--^{c}$ & $87 \%$ & $0 / 4$ & $26 / 30$ \\
\hline Shallow affect & $.00^{\mathrm{c}}$ & $--^{c}$ & $97 \%$ & $0 / 1$ & $29 / 30$ \\
\hline
\end{tabular}


Table 3 continued

Inter-Rater Reliability for the Childhood and Adolescent Risk Factors.

\begin{tabular}{|c|c|c|c|c|c|}
\hline \multirow[b]{2}{*}{ Risk Factor } & \multicolumn{5}{|c|}{$\begin{array}{c}\text { Time } 1 \\
\text { (No. of cases: } 30 \text { ) } \\
\text { (No. of raters: } 2 \text { ) } \\
\end{array}$} \\
\hline & $\begin{array}{l}\text { Generalized } \\
\text { Kappa }\end{array}$ & $\begin{array}{c}\text { Level of } \\
\text { Agreement }^{\mathrm{a}}\end{array}$ & $\begin{array}{c}\% \text { Total } \\
\text { Agreement } \\
\text { (agreed on } \\
\text { cases } / 30 * 100)\end{array}$ & $\begin{array}{l}\text { Proportion of } \\
\text { Agreement } \\
\text { for "Yes" } \\
\text { (agreed/total) }\end{array}$ & $\begin{array}{l}\text { Proportion } \\
\quad \text { of } \\
\text { Agreement } \\
\text { for "No" }\end{array}$ \\
\hline Lacks empathy & $--^{b}$ & $--^{b}$ & $100 \%$ & $0 / 0$ & $30 / 30$ \\
\hline $\begin{array}{l}\text { Lacks remorse or } \\
\text { guilt }\end{array}$ & $--^{b}$ & $--^{b}$ & $100 \%$ & $0 / 0$ & $30 / 30$ \\
\hline $\begin{array}{l}\text { Alcohol and/or drug use } \\
\text { in childhood }\end{array}$ & $.00^{c *}$ & $--^{c}$ & $97 \%$ & $\mathbf{0} / \mathbf{1}$ & $19 / 20$ \\
\hline $\begin{array}{l}\text { Alcohol and/or drug use } \\
\text { in adolescence }\end{array}$ & $.90 *$ & Excellent & $95 \%$ & $12 / 13$ & $7 / 8$ \\
\hline Alcohol & .38 & Fair & $67 \%$ & $11 / 21$ & $9 / 19$ \\
\hline Hallucinogens & .66 & Good & $83 \%$ & $9 / 14$ & $16 / 21$ \\
\hline Stimulants & .38 & Fair & $83 \%$ & $2 / 7$ & $23 / 28$ \\
\hline Opiates & $.00^{\mathrm{c}}$ & $--^{c}$ & $97 \%$ & $0 / 1$ & $29 / 30$ \\
\hline Other depressants & $--^{b}$ & $--{ }^{b}$ & $100 \%$ & $0 / 0$ & $30 / 30$ \\
\hline Drugs not specified & .52 & Moderate & $90 \%$ & $2 / 5$ & $25 / 28$ \\
\hline $\begin{array}{l}\text { Health problems in } \\
\text { childhood }\end{array}$ & $.76^{*}$ & Good & $92 \%$ & $4 / 6$ & $20 / 22$ \\
\hline $\begin{array}{l}\text { Health problems in } \\
\text { adolescence }\end{array}$ & $1.0 *$ & Excellent & $100 \%$ & $2 / 2$ & $24 / 24$ \\
\hline $\begin{array}{l}\text { Traumatic head } \\
\text { injury }\end{array}$ & .87 & Excellent & $97 \%$ & $4 / 5$ & $25 / 26$ \\
\hline Seizures & $.00^{\mathrm{c}}$ & $--^{c}$ & $93 \%$ & $0 / 2$ & $28 / 30$ \\
\hline Invasive surgery & $--{ }^{b}$ & $--^{b}$ & $100 \%$ & $0 / 0$ & $30 / 30$ \\
\hline Early ear infections & $--^{b}$ & $--^{b}$ & $100 \%$ & $0 / 0$ & $30 / 30$ \\
\hline Enuresis & $--{ }^{b}$ & $--^{b}$ & $100 \%$ & $0 / 0$ & $30 / 30$ \\
\hline Encopresis & $--{ }^{b}$ & $--{ }^{b}$ & $100 \%$ & $0 / 0$ & $30 / 30$ \\
\hline Obesity & $.00^{\mathrm{c}}$ & $--^{c}$ & $97 \%$ & $0 / 1$ & $29 / 30$ \\
\hline Hygiene problems & $--^{b}$ & $--^{b}$ & $100 \%$ & $0 / 0$ & $30 / 30$ \\
\hline $\begin{array}{l}\text { Other health } \\
\text { problems }\end{array}$ & .29 & $--{ }^{b}$ & $77 \%$ & $2 / 9$ & $21 / 28$ \\
\hline $\begin{array}{l}\text { Criminal family } \\
\text { members in childhood }\end{array}$ & -_b* & $--\mathbf{b}$ & $100 \%$ & $0 / 0$ & $27 / 27$ \\
\hline $\begin{array}{l}\text { Criminal family } \\
\text { members in } \\
\text { adolescence }\end{array}$ & $--\mathrm{b} *$ & $--b$ & $100 \%$ & $0 / 0$ & $27 / 27$ \\
\hline Criminal mother & $-{ }^{b}$ & $-{ }^{\mathrm{b}}$ & $100 \%$ & $0 / 0$ & $30 / 30$ \\
\hline
\end{tabular}


Table 3 continued

Inter-Rater Reliability for the Childhood and Adolescent Risk Factors.

\begin{tabular}{|c|c|c|c|c|c|}
\hline \multirow[b]{2}{*}{ Risk Factor } & \multicolumn{5}{|c|}{$\begin{array}{l}\text { Time } 1 \\
\text { (No. of cases: } 30) \\
\text { (No. of raters: } 2 \text { ) } \\
\end{array}$} \\
\hline & $\begin{array}{c}\text { Generalized } \\
\text { Kappa }\end{array}$ & $\begin{array}{c}\text { Level of } \\
\text { Agreement }^{\mathrm{a}}\end{array}$ & $\begin{array}{c}\% \text { Total } \\
\text { Agreement } \\
\text { (agreed on } \\
\text { cases } / 30 * 100)\end{array}$ & $\begin{array}{l}\text { Proportion of } \\
\text { Agreement } \\
\text { for "Yes" } \\
\text { (agreed/total) }\end{array}$ & $\begin{array}{l}\text { Proportion } \\
\quad \text { of } \\
\text { Agreement } \\
\text { for "No" }\end{array}$ \\
\hline Criminal father & $--^{b}$ & $--^{\mathrm{b}}$ & $100 \%$ & $0 / 0$ & $30 / 30$ \\
\hline Criminal sibling & .47 & Moderate & $93 \%$ & $1 / 3$ & $27 / 29$ \\
\hline $\begin{array}{l}\text { Parental } \\
\text { psychopathology in } \\
\text { childhood }\end{array}$ & $.64 *$ & Good & $95 \%$ & $1 / 2$ & $18 / 19$ \\
\hline $\begin{array}{l}\text { Parental } \\
\text { psychopathology in } \\
\text { adolescence }\end{array}$ & $--\mathbf{b}$ & $--\mathbf{b}$ & $100 \%$ & $0 / 0$ & $20 / 20$ \\
\hline $\begin{array}{l}\text { Mental health } \\
\text { difficulties - } \\
\text { mother }\end{array}$ & .87 & & $97 \%$ & $4 / 5$ & $25 / 26$ \\
\hline $\begin{array}{l}\text { Mental health } \\
\text { difficulties - father }\end{array}$ & 1.0 & Excellent & $100 \%$ & $2 / 2$ & $28 / 28$ \\
\hline $\begin{array}{l}\text { Psychiatric } \\
\text { hospitalization - } \\
\text { mother }\end{array}$ & $--{ }^{b}$ & $--^{b}$ & $100 \%$ & $0 / 0$ & $30 / 30$ \\
\hline $\begin{array}{l}\text { Psychiatric } \\
\text { hospitalization - } \\
\text { father }\end{array}$ & $--{ }^{b}$ & $--^{b}$ & $100 \%$ & $0 / 0$ & $30 / 30$ \\
\hline $\begin{array}{l}\text { Alcohol and/or drug } \\
\text { use - mother }\end{array}$ & $--^{b}$ & $--^{b}$ & $100 \%$ & $0 / 0$ & $30 / 30$ \\
\hline $\begin{array}{l}\text { Alcohol and or drug } \\
\text { use - father }\end{array}$ & .80 & Good & $93 \%$ & $5 / 7$ & $23 / 25$ \\
\hline $\begin{array}{l}\text { Prenatal drinking or } \\
\text { drug use }\end{array}$ & $--\mathrm{b}$ & $--^{b}$ & $100 \%$ & $0 / 0$ & $30 / 30$ \\
\hline $\begin{array}{l}\text { Broken home or family } \\
\text { transitions in } \\
\text { childhood }\end{array}$ & $.92 *$ & Excellent & $96 \%$ & $11 / 12$ & $12 / 13$ \\
\hline $\begin{array}{l}\text { Broken home or family } \\
\text { transitions in } \\
\text { adolescence }\end{array}$ & $-.07 *$ & Poor & $\mathbf{8 3 \%}$ & $0 / 4$ & $20 / 24$ \\
\hline Parental separation & .62 & Good & $83 \%$ & $7 / 12$ & $18 / 23$ \\
\hline Parental divorce & .62 & Good & $90 \%$ & $3 / 6$ & $24 / 27$ \\
\hline Single parent & .46 & Moderate & $77 \%$ & $6 / 13$ & $17 / 24$ \\
\hline
\end{tabular}


Table 3 continued

Inter-Rater Reliability for the Childhood and Adolescent Risk Factors.

\begin{tabular}{|c|c|c|c|c|c|}
\hline \multirow[b]{2}{*}{ Risk Factor } & \multicolumn{5}{|c|}{$\begin{array}{l}\text { Time } 1 \\
\text { (No. of cases: } 30) \\
\text { (No. of raters: } 2 \text { ) }\end{array}$} \\
\hline & $\begin{array}{c}\text { Generalized } \\
\text { Kappa }\end{array}$ & $\begin{array}{c}\text { Level of } \\
\text { Agreement }^{\mathrm{a}}\end{array}$ & $\begin{array}{c}\text { \% Total } \\
\text { Agreement } \\
\text { (agreed on } \\
\text { cases } / 30 * 100)\end{array}$ & $\begin{array}{l}\text { Proportion of } \\
\text { Agreement } \\
\text { for "Yes" } \\
\text { (agreed/total) }\end{array}$ & $\begin{array}{l}\text { Proportion } \\
\quad \text { of } \\
\text { Agreement } \\
\text { for "No" }\end{array}$ \\
\hline Parental remarriage & .44 & Moderate & $77 \%$ & $3 / 8$ & $22 / 27$ \\
\hline Frequent moving & .71 & Good & $93 \%$ & $3 / 5$ & $25 / 27$ \\
\hline $\begin{array}{l}\text { Frequent change in } \\
\text { parental figures }\end{array}$ & .52 & Moderate & $90 \%$ & $2 / 5$ & $25 / 28$ \\
\hline $\begin{array}{l}\text { Involvement with } \\
\text { alternative care in } \\
\text { childhood }\end{array}$ & .65 & Good & $97 \%$ & $1 / 2$ & $28 / 29$ \\
\hline $\begin{array}{l}\text { Involvement with } \\
\text { alternative care in } \\
\text { adolescence }\end{array}$ & .37 & Fair & $90 \%$ & $1 / 4$ & $26 / 29$ \\
\hline Child welfare agency & .65 & Good & $97 \%$ & $1 / 2$ & $28 / 29$ \\
\hline Foster care & 1.0 & Excellent & $100 \%$ & $1 / 1$ & $29 / 29$ \\
\hline Adopted & $--^{b}$ & $--^{\mathrm{b}}$ & $100 \%$ & $0 / 0$ & $30 / 30$ \\
\hline $\begin{array}{l}\text { Other institutional } \\
\text { involvement }\end{array}$ & $.00^{c}$ & $--^{c}$ & $90 \%$ & $0 / 3$ & $27 / 30$ \\
\hline $\begin{array}{l}\text { Trauma, abuse or } \\
\text { neglect in childhood }\end{array}$ & $.78 *$ & Good & $91 \%$ & $5 / 7$ & $16 / 18$ \\
\hline $\begin{array}{l}\text { Trauma, abuse or } \\
\text { neglect in adolescence }\end{array}$ & $.70 *$ & Good & $91 \%$ & $3 / 5$ & $18 / 20$ \\
\hline Sexual abused & .71 & Good & $93 \%$ & $3 / 5$ & $25 / 27$ \\
\hline Physical abused & .63 & Good & $87 \%$ & $5 / 9$ & $21 / 25$ \\
\hline $\begin{array}{l}\text { Verbal or emotional } \\
\text { abused }\end{array}$ & 1.0 & Excellent & $100 \%$ & $3 / 3$ & $27 / 27$ \\
\hline $\begin{array}{l}\text { Witnessed physical } \\
\text { abuse }\end{array}$ & 1.0 & Excellent & $100 \%$ & $3 / 3$ & $27 / 27$ \\
\hline Witnessed sexual abuse & 1.0 & Excellent & $100 \%$ & $1 / 1$ & $29 / 29$ \\
\hline $\begin{array}{l}\text { Witnessed verbal or } \\
\text { emotional abuse }\end{array}$ & 1.0 & Excellent & $100 \%$ & $1 / 1$ & $29 / 29$ \\
\hline Neglect & $.00^{\mathrm{c}}$ & $--^{c}$ & $97 \%$ & $0 / 1$ & $29 / 30$ \\
\hline Other trauma & .29 & Fair & $87 \%$ & $1 / 5$ & $25 / 29$ \\
\hline
\end{tabular}

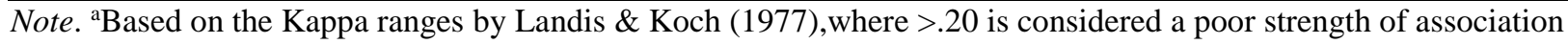
while $.21-.40$ is fair, 41-.60 is moderate, .61-.80 is good, and .80-1.00 is excellent. Values lower than .00 represent agreement that is worse than would be expected by chance. ${ }^{b}$ Kappa could not be calculated because the variable is a constant. 'Kappa is .00 because one of the two coders coded no cases as present, while the other coded some number of cases present. *rater 2 coded age of occurrence as unknown for more than one patient, thereby making the variable for that individual "missing," resulting in less than 30 cases in total. 
Several issues emerged in calculating interrater reliability. Firstly, the base rate of occurrence for many indicators of categories of developmental risk factors was very low (e.g., having a learning disability was rare, whereas low intelligence or poor academic achievement, the category encompassing learning disabilities as one of several potential indicators, was more common). Thus, Kappa tended to be very low if there was any disagreement. This was true for the opposite; Kappa was inflated in cases where there was only one case of occurrence of an indicator of a developmental risk factor, and both raters agreed on the case. This issue was more often present for single items in a risk factor category, as the occurrence of indicators of a category developmental was rarer than the occurrence of that risk factor category.

Secondly, the second coder tended to omit the age of occurrence of risk factors. As categories of developmental risk factors were coded as occurring in childhood or in adolescence, omitting the age of occurrence resulted in a missing variable for that individual. As such, some categories of developmental risk factors contain less than 30 cases. These omissions were likely due to the fact that reports used for coding occasionally did not contain an exact age of occurrence. Instead, reports occasionally described the school grade at which a risk factor occurred, or they followed a chronological narrative of the individual's development, stating risk factors as they occurred, without specifying the age. The second coder may have been more conservative with estimates of age of occurrence, not specifying when the risk factor occurred unless it was clearly stated. The first coder would estimate the age of occurrence from either the school grade during which the risk factor occurred, or by using clues in the chronological narrative to infer the age. For example, if a report covered an individual's course in secondary school, and subsequently stated that they were involved in physical altercations with peers, the 
first coder would code the physical aggression as occurring in adolescence, as it was mentioned in the section covering the patient's course during that age range.

\section{Plan of Analysis}

Analyses were performed using the Statistical Package for the Social Sciences (SPSS) Version 16. Analyses were first conducted on the combined sample $(n=150)$. Analyses for model building followed guidelines by Hosmer \& Lemeshow (2004). This method is particularly useful for selecting variables for inclusion in the model when there are many independent variables. First, cross tabulations were conducted with the chi-square test of independence to analyse whether there is an association between developmental risk factors that occurred in childhood and adolescence, respectively, and adverse events for patients found NCRMD. Variables with a base rate of less than $10 \%$ were not included in analyses. Following the cross tabulations, all predictors with a significance value of $p<.25$ that did not contain a zero cell were included in the logistic regression. Importance of predictors in the model was assessed using the log likelihood and Wald statistics. Risk factors occurring in childhood and adolescence were analyzed in separate models. In order to determine whether developmental risk factors predicted adverse events above and beyond traditional risk assessments, a hierarchical logistic regression was conducted, regressing adverse events on developmental risk factors, while controlling for total score on the HCR-20. Total score on the HCR-20 was entered into the first block, and risk factors occurring in childhood or adolescence were entered into the second block.

In order to assess differences in developmental risk factors that predict adverse events for male and female patients, a second set of analyses was conducted for male and female patients separately. First, cross tabulations with chi-square test of independence were conducted for risk factors occurring in childhood and adolescence, respectively, and adverse events. Developmental 
risk factors were not included in this analysis if they had a base rate of less than $10 \%$. Any risk factor that had a significance level of $\mathrm{p}<.25$ was included in the logistic regression. Separate logistic regressions were conducted for risk factors occurring in childhood and adolescence for male and female patients. 


\section{Results}

\section{Preliminary Analyses}

There was no difference in frequency of adverse events among those who had sufficient

developmental information to be included in coding and those who did not, $X^{2}(1, N=169)=.331$, $p>.05$. As such, it is not likely that patients excluded from further analyses significantly differed from those who were included in final analyses.

Descriptive statistics were calculated to show the prevalence of developmental risk factors and adverse events for the combined sample and for male and female patients separately. Chi-square analyses indicated significant differences between male and female patients on several developmental risk factors. There was a greater prevalence of problems in school in childhood for males $(17 \%)$ than for females $(0 \% ; p<.05)$. More male patients had hyperactivity, impulsivity, or inattention symptoms in childhood $(13 \%)$ than female patients $(2 \% ; p<.05)$. In terms of risk factors occurring in adolescence, more male patients $(48 \%)$ than female patients $(22 \%)$ exhibited antisocial behaviour $(p<.05)$, and more male patients $(57 \%)$ than female patients $(32 \%)$ engaged in substance use $(p<.05)$. More female patients $(4 \%)$ had family with criminal involvement in adolescence than male patients $(0 \% ; p<.05)$, and more female patients $(22 \%)$ had parents with psychopathology in adolescence than male patients $(7 \% ; p<.05)$. In terms of adverse events, while male and female patients differed on prevalence of some specific adverse events, there was no difference between male (68\%) and female $(68 \%)$ patients on prevalence of experiencing an adverse event, when all specific events were grouped together as one variable $(p=1.00)$. Frequencies of developmental risk factors and adverse events for the combined sample and for male and female patients are presented in Tables 4 and 5, respectively. 
Table 4

Frequencies of Developmental Risk Factors for the Combined Sample and Males and Females Separately

\begin{tabular}{|c|c|c|c|c|c|}
\hline \multirow[b]{2}{*}{ Risk factor } & $\begin{array}{l}\text { Combined } \\
\text { sample } \\
(\mathrm{n}=150)\end{array}$ & $\begin{array}{c}\text { Males } \\
(\mathrm{n}=100)\end{array}$ & $\begin{array}{c}\text { Females } \\
(n=50)\end{array}$ & \multirow[t]{2}{*}{$X^{2}$} & \multirow[t]{2}{*}{$\phi$} \\
\hline & $\begin{array}{l}\text { Frequency } \\
\text { (Percent) }\end{array}$ & $\begin{array}{l}\text { Frequency } \\
\text { (Percent) }\end{array}$ & $\begin{array}{l}\text { Frequency } \\
\text { (Percent) }\end{array}$ & & \\
\hline $\begin{array}{l}\text { Low intelligence or poor } \\
\text { academic achievement in } \\
\text { childhood }\end{array}$ & $39(26 \%)$ & $29(29 \%)$ & $10(10 \%)$ & 1.403 & -.097 \\
\hline $\begin{array}{l}\text { Low intelligence or poor } \\
\text { academic achievement in } \\
\text { adolescence }\end{array}$ & $87(58 \%)$ & $63(63 \%)$ & $24(48 \%)$ & 3.079 & -.143 \\
\hline $\begin{array}{l}\text { Problems at school in } \\
\text { childhood }\end{array}$ & $17(11 \%)$ & $17(17 \%)$ & $0(0 \%)$ & $9.554^{*}$ & $-.259 *$ \\
\hline $\begin{array}{l}\text { Problems at school in } \\
\text { adolescence }\end{array}$ & $54(36 \%)$ & $42(42 \%)$ & $12(24 \%)$ & $4.655^{*}$ & -.181 \\
\hline $\begin{array}{l}\text { Hyperactivity- } \\
\text { impulsivity-inattention in } \\
\text { childhood }\end{array}$ & $14(9 \%)$ & $13(13 \%)$ & $1(2 \%)$ & $4.776^{*}$ & $-.180 *$ \\
\hline $\begin{array}{l}\text { Hyperactivity- } \\
\text { impulsivity-inattention in } \\
\text { adolescence }\end{array}$ & $5(3 \%)$ & $3(3 \%)$ & $2(4 \%)$ & 0.101 & .027 \\
\hline $\begin{array}{l}\text { Antisocial behaviour in } \\
\text { childhood }\end{array}$ & $31(21 \%)$ & $25(25 \%)$ & $6(12 \%)$ & 3.454 & -.153 \\
\hline $\begin{array}{l}\text { Antisocial behaviour in } \\
\text { adolescence }\end{array}$ & $59(39 \%)$ & $48(48 \%)$ & $11(22 \%)$ & $9.4431 *$ & $-.255^{*}$ \\
\hline $\begin{array}{l}\text { Alcohol and/or drug use } \\
\text { in childhood }\end{array}$ & $7(5 \%)$ & $4(4 \%)$ & $3(6 \%)$ & 0.289 & .045 \\
\hline $\begin{array}{l}\text { Alcohol and/or drug use } \\
\text { in adolescence }\end{array}$ & $73(49 \%)$ & $57(57 \%)$ & $16(32 \%)$ & $8.339 *$ & $-.236^{*}$ \\
\hline $\begin{array}{l}\text { Health problems in } \\
\text { childhood }\end{array}$ & $41(27 \%)$ & $30(30 \%)$ & $11(22 \%)$ & 1.148 & -.088 \\
\hline
\end{tabular}


Table 4 continued

Frequencies of Developmental Risk Factors for the Combined Sample and Males and Females Separately

\begin{tabular}{|c|c|c|c|c|c|}
\hline \multirow[b]{2}{*}{ Risk factor } & \multirow{2}{*}{$\begin{array}{c}\text { Combined } \\
\text { sample } \\
(\mathrm{n}=150)\end{array}$} & \multirow{2}{*}{$\begin{array}{c}\text { Males } \\
(\mathrm{n}=100)\end{array}$} & \multirow{2}{*}{$\begin{array}{c}\begin{array}{c}\text { Females } \\
(\mathrm{n}=50)\end{array} \\
\begin{array}{c}\text { Frequency } \\
\text { (Percent) }\end{array}\end{array}$} & \multirow[t]{2}{*}{$X^{2}$} & \multirow[t]{2}{*}{$\phi$} \\
\hline & & & & & \\
\hline $\begin{array}{l}\text { Health problems in } \\
\text { adolescence }\end{array}$ & $7(5 \%)$ & $4(4 \%)$ & $3(6 \%)$ & 0.285 & .044 \\
\hline $\begin{array}{l}\text { Criminal family } \\
\text { members in childhood }\end{array}$ & $1(0.7 \%)$ & $0(0 \%)$ & $1(2 \%)$ & 2.156 & .116 \\
\hline $\begin{array}{l}\text { Criminal family } \\
\text { members in adolescence }\end{array}$ & $2(1 \%)$ & $0(0 \%)$ & $2(4 \%)$ & $4.339 *$ & .165 \\
\hline $\begin{array}{l}\text { Parental } \\
\text { psychopathology in } \\
\text { childhood }\end{array}$ & $19(13 \%)$ & $14(14 \%)$ & $5(10 \%)$ & 0.275 & -.047 \\
\hline $\begin{array}{l}\text { Parental } \\
\text { psychopathology in } \\
\text { adolescence }\end{array}$ & $7(5 \%)$ & $7(7 \%)$ & $11(22 \%)$ & $5.477^{*}$ & $-.166^{*}$ \\
\hline $\begin{array}{l}\text { Broken home or family } \\
\text { transitions in childhood }\end{array}$ & $69(46 \%)$ & $42(42 \%)$ & $27(54 \%)$ & 1.790 & .110 \\
\hline $\begin{array}{l}\text { Broken home or family } \\
\text { transitions in adolescence }\end{array}$ & $33(22 \%)$ & $21(21 \%)$ & $12(24 \%)$ & 0.150 & .032 \\
\hline $\begin{array}{l}\text { Involvement with } \\
\text { alternative care in } \\
\text { childhood }\end{array}$ & $6(4 \%)$ & $4(4 \%)$ & $2(4 \%)$ & 1.000 & .000 \\
\hline $\begin{array}{l}\text { Involvement with } \\
\text { alternative care in } \\
\text { adolescence }\end{array}$ & $8(5 \%)$ & $6(6 \%)$ & $2(4 \%)$ & 0.264 & -.042 \\
\hline $\begin{array}{l}\text { Trauma, abuse or neglect } \\
\text { in childhood }\end{array}$ & $40(27 \%)$ & $27(27 \%)$ & $13(26 \%)$ & 0.003 & .004 \\
\hline $\begin{array}{l}\text { Trauma, abuse or neglect } \\
\text { in adolescence }\end{array}$ & $21(14 \%)$ & $14(14 \%)$ & $7(14 \%)$ & 0.015 & .010 \\
\hline
\end{tabular}


Table 5

Frequencies of Adverse Events for the Combined Sample and Males and Females Separately

\begin{tabular}{|c|c|c|c|c|c|}
\hline & $\begin{array}{l}\text { Combined } \\
\text { sample } \\
(\mathrm{n}=150)\end{array}$ & $\begin{array}{c}\text { Males } \\
(\mathrm{n}=100)\end{array}$ & $\begin{array}{c}\text { Females } \\
(\mathrm{n}=50)\end{array}$ & \multirow[t]{2}{*}{$X^{2}$} & \multirow[t]{2}{*}{$\phi$} \\
\hline Adverse event & $\begin{array}{l}\text { Frequency } \\
\text { (Percent) }\end{array}$ & $\begin{array}{l}\text { Frequency } \\
\text { (Percent) }\end{array}$ & $\begin{array}{l}\text { Frequency } \\
\text { (Percent) }\end{array}$ & & \\
\hline Placed in seclusion & $21(14 \%)$ & $14(14 \%)$ & $7(14 \%)$ & 0.167 & .041 \\
\hline Restraint use & $5(3 \%)$ & $1(1 \%)$ & $4(8 \%)$ & $6.373^{*}$ & $.251 *$ \\
\hline $\begin{array}{l}\text { Verbal or physical } \\
\text { violence }\end{array}$ & $49(33 \%)$ & $14(14 \%)$ & $15(30 \%)$ & 0.242 & -.040 \\
\hline $\begin{array}{l}\text { Suicide attempts, } \\
\text { ideation, or self-harm }\end{array}$ & $11(7 \%)$ & $4(4 \%)$ & $7(14 \%)$ & $4.905^{*}$ & $.181 *$ \\
\hline $\begin{array}{l}\text { Homicidal attempts or } \\
\text { violent ideation }\end{array}$ & $15(10 \%)$ & $11(11 \%)$ & $4(8 \%)$ & 0.333 & -.047 \\
\hline $\begin{array}{l}\text { Conflicts with staff or } \\
\text { patients }\end{array}$ & $53(35 \%)$ & $34(34 \%)$ & $19(38 \%)$ & 0.233 & .039 \\
\hline Victimization & $14(9 \%)$ & $8(8 \%)$ & $6(12 \%)$ & 0.630 & .065 \\
\hline AWOL & $20(13 \%)$ & $12(12 \%)$ & $8(16 \%)$ & 0.462 & .055 \\
\hline New charges under ORB & $3(2 \%)$ & $2(2 \%)$ & $1(2 \%)$ & 0.000 & .000 \\
\hline Substance abuse relapses & $26(17 \%)$ & $18(18 \%)$ & $8(16 \%)$ & 0.093 & -.025 \\
\hline Any other breaches & $3(2 \%)$ & $0(0 \%)$ & $3(6 \%)$ & $6.122 *$ & $.202 *$ \\
\hline Hospital readmission & $12(8 \%)$ & $3(3 \%)$ & $8(18 \%)$ & $10.190 *$ & $.261 *$ \\
\hline $\begin{array}{l}\text { Medication refusal or } \\
\text { noncompliance }\end{array}$ & $44(33 \%)$ & $25(25 \%)$ & $19(38 \%)$ & 2.410 & .114 \\
\hline Any adverse event & $102(68 \%)$ & $68(68 \%)$ & $34(68 \%)$ & 0.000 & .000 \\
\hline
\end{tabular}

$* p<.05$

\section{Hypothesis Testing}

Combined sample. To answer the second research question, Chi-square was computed for all developmental risk factor categories with a base rate of $10 \%$ or greater and adverse events. Risk factors occurring in childhood were analysed separately from those occurring in adolescence, and the results are presented in Tables 6 and 7, respectively. There were no 
Table 6

Cross Tabulation of Childhood Risk Factors and Any Adverse Event for the Combined Sample

\begin{tabular}{lcccc}
\hline \multicolumn{1}{c}{ Risk factor } & $X^{2}$ & df & $\phi$ & Significance \\
\hline $\begin{array}{l}\text { Low intelligence or } \\
\text { academic achievement }\end{array}$ & .037 & 1 & .016 & .848 \\
$\begin{array}{l}\text { Problems in school } \\
\text { Antisocial behaviour }\end{array}$ & .074 & 1 & -.023 & .785 \\
$\begin{array}{l}\text { Health Problems } \\
\begin{array}{l}\text { Parental } \\
\text { psychopathology }\end{array}\end{array}$ & .687 & 1 & .068 & .407 \\
$\begin{array}{l}\text { Broken home or family } \\
\text { transitions }\end{array}$ & .198 & 1 & .039 & .635 \\
$\begin{array}{l}\text { Trauma, neglect, or } \\
\text { abuse }\end{array}$ & 1.772 & 1 & .040 & .656 \\
\hline
\end{tabular}

Table 7

Cross Tabulation of Adolescent Risk Factors and Any Adverse Event for the Combined Sample

\begin{tabular}{|c|c|c|c|c|}
\hline Risk factor & $X^{2}$ & df & $\phi$ & Significance \\
\hline $\begin{array}{l}\text { Low intelligence or } \\
\text { academic achievement }\end{array}$ & 4.289 & 1 & .169 & $.038 *$ \\
\hline Problems in school & 4.117 & 1 & .170 & $.042 *$ \\
\hline Antisocial behaviour & 3.080 & 1 & .145 & .079 \\
\hline Substance use & .227 & 1 & .039 & .634 \\
\hline $\begin{array}{l}\text { Broken home or family } \\
\text { transitions }\end{array}$ & .041 & 1 & .014 & .839 \\
\hline $\begin{array}{l}\text { Trauma, neglect, or } \\
\text { abuse }\end{array}$ & 5.497 & 1 & .196 & $.019 *$ \\
\hline
\end{tabular}

$* p<.05$

differences in childhood risk factors for patients who experienced an adverse event during the coded clinical year and those who did not experience an adverse event. However, significant differences emerged for risk factors occurring in adolescence between patients who experienced an adverse event during the coded clinical year and those who did not. Specifically, $46 \%$ of those who did not experience an adverse event had low intelligence or poor academic achievement in 
Table 8

Logistic Regression of Childhood Risk Factors and Any Adverse Event for the Combined Sample

\begin{tabular}{|c|c|c|c|c|c|c|c|c|}
\hline \multirow[t]{2}{*}{ Predictor } & \multirow[t]{2}{*}{ B } & \multirow[t]{2}{*}{ S.E. } & \multirow[t]{2}{*}{ Wald } & \multirow[t]{2}{*}{$\mathrm{df}$} & \multirow[t]{2}{*}{ Sig. } & \multirow[t]{2}{*}{$\operatorname{Exp}(B)$} & \multicolumn{2}{|c|}{$\begin{array}{c}95 \% \text { C.I. } \\
\text { for } \operatorname{Exp}(\mathrm{B})\end{array}$} \\
\hline & & & & & & & Lower & Upper \\
\hline Constant & .510 & .260 & 3.857 & 1 & .050 & 1.665 & & \\
\hline $\begin{array}{l}\text { Broken home } \\
\text { or family } \\
\text { transitions }\end{array}$ & .325 & .370 & .771 & 1 & .380 & 1.384 & .670 & 2.861 \\
\hline $\begin{array}{l}\text { Trauma, } \\
\text { abuse or } \\
\text { neglect }\end{array}$ & .555 & .435 & 1.631 & 1 & .202 & 1.742 & .743 & 4.083 \\
\hline
\end{tabular}

Table 9

Logistic Regression of Adolescent Risk Factors and Any Adverse Event for the Combined Sample

\begin{tabular}{|c|c|c|c|c|c|c|c|c|}
\hline \multirow[t]{2}{*}{ Predictor } & \multirow[t]{2}{*}{$\mathrm{B}$} & \multirow[t]{2}{*}{ S.E. } & \multirow[t]{2}{*}{ Wald } & \multirow[t]{2}{*}{ df } & \multirow[t]{2}{*}{ Sig. } & \multirow{2}{*}{$\begin{array}{l}\text { Exp } \\
\text { (B) }\end{array}$} & \multicolumn{2}{|c|}{$\begin{array}{l}95 \% \text { C.I. } \\
\text { for } \operatorname{Exp}(\mathrm{B})\end{array}$} \\
\hline & & & & & & & Lower & Upper \\
\hline Constant & .062 & .297 & .043 & 1 & .836 & 1.064 & & \\
\hline $\begin{array}{l}\text { Low } \\
\text { intelligence or } \\
\text { academic } \\
\text { achievement }\end{array}$ & .565 & .424 & 1.776 & 1 & .183 & 1.759 & .767 & 4.035 \\
\hline $\begin{array}{l}\text { Problems at } \\
\text { school }\end{array}$ & .546 & .500 & 1.193 & 1 & .275 & 1.727 & .648 & 4.602 \\
\hline $\begin{array}{l}\text { Antisocial } \\
\text { behaviour }\end{array}$ & .159 & .480 & .110 & 1 & .740 & 1.172 & .458 & 3.000 \\
\hline $\begin{array}{l}\text { Trauma, abuse } \\
\text { or neglect }\end{array}$ & 2.102 & 1.057 & 3.959 & 1 & .047 & 8.185 & 1.032 & $64.921 *$ \\
\hline \multicolumn{9}{|l|}{$* p<.05$} \\
\hline \multicolumn{9}{|c|}{ adolescence, compared to $64 \%$ of those who experienced an adverse event $(p<.05)$. } \\
\hline \multicolumn{9}{|c|}{ Additionally, there was a greater prevalence of problems at school for those who experienced an } \\
\hline \multicolumn{9}{|c|}{ adverse event $(44 \%)$ than those who did not experience an adverse event $(26 \% ; p<.05)$. Finally, } \\
\hline
\end{tabular}


Results of the logistic regression for childhood risk factors are presented in Table 8. After eliminating risk factors according to the criteria by Hosmer and Lemeshow (2004), broken home or family transitions, and trauma, abuse, or neglect were entered into the model. Variance inflation factors (VIF) for childhood risk factors ranged from 1.095 to 1.229 , indicating that there was a small to moderate correlation among the risk factors occurring in childhood. No VIFs reached 5; thus there was no problematic collinearity among the predictors (Akinwande, Dikko, \& Samson, 2015). The model for childhood risk factors predicting an adverse event was not significant, $X^{2}(2, \mathrm{~N}=150)=2.724, p=.256$.

Risk factors occurring in adolescence that were entered into the model included low intelligence or academic achievement, problems in school, antisocial behaviour, and trauma, abuse or neglect. The model including only risk factors occurring in adolescence is presented in Table 9. VIF for risk factors occurring in adolescence ranged from 1.038 to 1.956 , indicating that there were small to moderate correlations among the predictors. The model for adolescent risk factors predicting an adverse event was significant, $X^{2}(4, \mathrm{~N}=150)=13.779, p<.05$. The Nagelkerke pseudo $\mathrm{R}^{2}$ statistic indicated that $13.8 \%$ of the variance in adverse events was predicted by the variables in the model. In terms of specific predictors, only trauma, abuse, and neglect was significant $(p<.05)$.

In order to determine whether developmental risk factors predicted adverse events above and beyond traditional risk assessments, total score on the HCR-20 was entered into the first block, and risk factors occurring in adolescence were entered into the second block. Results are presented in Table 10. The first block was significant, $X^{2}(1, \mathrm{~N}=150)=60.360, p<.05 . \mathrm{HCR}-20$ total score predicted $49.6 \%$ of the variance in adverse events, and accurately classified $79.9 \%$ of cases. The second block, containing adolescent risk factors was not significant, $X^{2}(3, \mathrm{~N}=150)=$ 
Table 10

Logistic Regression of Adolescent Risk Factors and Any Adverse Event for the Combined Sample Controlling for HCR-20 Total Score

\begin{tabular}{|c|c|c|c|c|c|c|c|c|}
\hline \multirow[t]{2}{*}{ Predictor } & \multirow[t]{2}{*}{ B } & \multirow[t]{2}{*}{ S.E. } & \multirow[t]{2}{*}{ Wald } & \multirow[t]{2}{*}{$\mathrm{df}$} & \multirow[t]{2}{*}{ Sig. } & \multirow{2}{*}{$\begin{array}{l}\operatorname{Exp} \\
(\mathrm{B})\end{array}$} & \multicolumn{2}{|c|}{$\begin{array}{c}95 \% \text { C.I. } \\
\text { for } \operatorname{Exp}(\mathrm{B})\end{array}$} \\
\hline & & & & & & & Lower & Upper \\
\hline Constant & -6.233 & 1.283 & 23.609 & 1 & .000 & .002 & & \\
\hline $\begin{array}{l}\text { HCR-20 total } \\
\text { score }\end{array}$ & .358 & .069 & 27.291 & 1 & .000 & 1.431 & 1.251 & 1.636 \\
\hline $\begin{array}{l}\text { Low } \\
\text { intelligence or } \\
\text { academic } \\
\text { achievement }\end{array}$ & .652 & .556 & 1.375 & 1 & .241 & 1.920 & .645 & 5.714 \\
\hline $\begin{array}{l}\text { Problems at } \\
\text { school }\end{array}$ & .561 & .645 & .758 & 1 & .384 & 1.753 & .495 & 6.202 \\
\hline $\begin{array}{l}\text { Antisocial } \\
\text { behaviour }\end{array}$ & -1.527 & .701 & 4.741 & 1 & .029 & .217 & .055 & $.859 *$ \\
\hline $\begin{array}{l}\text { Trauma, abuse } \\
\text { or neglect }\end{array}$ & 1.888 & 1.132 & 2.781 & 1 & .095 & 6.605 & .718 & 60.721 \\
\hline
\end{tabular}

$1.405, p=.704$, while the overall model remained significant, $X^{2}(4, \mathrm{~N}=150)=61.766, p=<.05$.

The Nagelkerke pseudo $\mathrm{R}^{2}$ statistic indicated that $50.5 \%$ of the variance in adverse events was accounted for by the predictors in this model, and $82.7 \%$ of cases were correctly classified. In terms of specific predictors, HCR-20 total score was significant $(p<.05)$, as was antisocial behaviour in adolescence $(p<.05)$.

Analyses by gender. To answer the fifth research question, Chi-square analyses were done for all developmental risk factor categories with a base rate of $10 \%$ or greater and adverse events for male and female patients separately. Cross tabulation analyses of childhood and adolescent risk factors and adverse events for male patients are present in Tables 11 and 12, respectively. No significant differences emerged between male patients who experienced an adverse event and 
Table 11

Cross Tabulation of Childhood Risk Factors and Any Adverse Event for Male Patients

\begin{tabular}{lcccc}
\hline \multicolumn{1}{c}{ Risk factor } & $X^{2}$ & df & $\phi$ & Significance \\
\hline $\begin{array}{l}\text { Low intelligence or } \\
\text { academic } \\
\text { achievement }\end{array}$ & .017 & 1 & .013 & .895 \\
$\begin{array}{l}\text { Problems in school } \\
\text { Symptoms of ADHD }\end{array}$ & .132 & 1 & -.037 & .716 \\
$\begin{array}{l}\text { Antisocial behaviour } \\
\text { Health Problems }\end{array}$ & .205 & 1 & .137 & .176 \\
$\begin{array}{l}\text { Parental } \\
\text { psychopathology }\end{array}$ & .630 & 1 & .046 & .651 \\
$\begin{array}{l}\text { Parental separation or } \\
\text { frequent moving }\end{array}$ & 1.910 & 1 & .080 & .428 \\
$\begin{array}{l}\text { Trauma, neglect, or } \\
\text { abuse }\end{array}$ & .626 & 1 & .067 & .536 \\
\hline
\end{tabular}

Table 12

Cross Tabulation of Adolescent Risk Factors and Any Adverse Event for Male Patients

\begin{tabular}{|c|c|c|c|c|}
\hline Risk factor & $X^{2}$ & $\mathrm{df}$ & $\phi$ & Significance \\
\hline $\begin{array}{l}\text { Low intelligence or } \\
\text { academic } \\
\text { achievement }\end{array}$ & 1.969 & 1 & .140 & .161 \\
\hline Problems in school & 5.471 & 1 & .240 & $.019 *$ \\
\hline $\begin{array}{l}\text { Antisocial } \\
\text { behaviour }\end{array}$ & 1.914 & 1 & .140 & .167 \\
\hline Substance use & .108 & 1 & -.033 & .742 \\
\hline $\begin{array}{l}\text { Parental separation } \\
\text { or frequent moving }\end{array}$ & .051 & 1 & -.023 & .822 \\
\hline $\begin{array}{l}\text { Trauma, neglect, or } \\
\text { abuse }\end{array}$ & 2.350 & 1 & .159 & .125 \\
\hline
\end{tabular}

$* p<.05$ 
Table 13

Cross Tabulation of Childhood Risk Factors and Any Adverse Event for Female Patients

\begin{tabular}{lcccc}
\hline \multicolumn{1}{c}{ Risk factor } & $X^{2}$ & $\mathrm{df}$ & $\phi$ & Significance \\
\hline $\begin{array}{l}\text { Low intelligence or } \\
\text { academic }\end{array}$ & .023 & 1 & .021 & .880 \\
$\begin{array}{l}\text { achievement } \\
\text { Antisocial behaviour }\end{array}$ & .881 & 1 & .127 & .348 \\
$\begin{array}{l}\text { Health problems } \\
\begin{array}{l}\text { Parental } \\
\text { psychopathology }\end{array}\end{array}$ & .123 & 1 & -.050 & .725 \\
$\begin{array}{l}\text { Parental separation or } \\
\text { frequent moving } \\
\begin{array}{l}\text { Trauma, neglect, or } \\
\text { abuse }\end{array}\end{array}$ & .041 & 1 & -.033 & .839 \\
\hline
\end{tabular}

Table 14

Cross Tabulation of Adolescent Risk Factors and Any Adverse Event for Female Patients

\begin{tabular}{lcccc}
\hline \multicolumn{1}{c}{ Risk factor } & $X^{2}$ & df & $\phi$ & Significance \\
\hline $\begin{array}{l}\text { Low intelligence or } \\
\text { academic } \\
\text { achievement }\end{array}$ & 2.645 & 1 & .230 & .104 \\
$\begin{array}{l}\text { Problems in school } \\
\begin{array}{l}\text { Antisocial } \\
\text { behaviour }\end{array}\end{array}$ & .004 & 1 & .009 & .952 \\
$\begin{array}{l}\text { Substance use } \\
\begin{array}{l}\text { Broken home or } \\
\text { family transitions } \\
\text { Trauma, abuse, or } \\
\text { neglect }\end{array}\end{array}$ & 1.351 & 1 & .166 & .254 \\
$* p<.05$ & 5.614 & 1 & .195 & .168 \\
\hline$p<5$ & 1 & .084 & .551 \\
\hline
\end{tabular}

those who did not experience an adverse event on childhood risk factors. However, significantly more male patients who experienced an adverse event (52\%) had problems at school in childhood than those who did not experience an adverse event $(27 \% ; p<.05)$. There were no 
Table 15

Logistic Regression of Childhood Risk Factors and Any Adverse Event for Male Patients

\begin{tabular}{|c|c|c|c|c|c|c|c|c|}
\hline \multirow[t]{2}{*}{ Predictor } & \multirow[t]{2}{*}{ B } & \multirow[t]{2}{*}{ S.E. } & \multirow[t]{2}{*}{ Wald } & \multirow[t]{2}{*}{$\mathrm{df}$} & \multirow[t]{2}{*}{ Sig. } & \multirow[t]{2}{*}{$\operatorname{Exp}(B)$} & \multicolumn{2}{|c|}{$\begin{array}{c}95 \% \text { C.I. } \\
\text { for } \operatorname{Exp}(\mathrm{B})\end{array}$} \\
\hline & & & & & & & Lower & Upper \\
\hline Constant & .311 & .309 & 1.013 & 1 & .314 & 1.364 & & \\
\hline $\begin{array}{l}\text { Symptoms of } \\
\text { ADHD }\end{array}$ & .857 & .819 & 1.095 & 1 & .219 & 2.356 & .473 & 11.725 \\
\hline $\begin{array}{l}\text { Parental } \\
\text { separation or } \\
\text { frequent } \\
\text { moving }\end{array}$ & .479 & .469 & 1.041 & 1 & .308 & 1.614 & .643 & 4.048 \\
\hline
\end{tabular}

Table 16

Logistic Regression of Adolescent Risk Factors and Any Adverse Event for Male Patients

\begin{tabular}{|c|c|c|c|c|c|c|c|c|}
\hline \multirow[t]{2}{*}{ Predictor } & \multirow[t]{2}{*}{ B } & \multirow[t]{2}{*}{ S.E. } & \multirow[t]{2}{*}{ Wald } & \multirow[t]{2}{*}{ df } & \multirow[t]{2}{*}{ Sig. } & \multirow[t]{2}{*}{$\operatorname{Exp}(B)$} & \multicolumn{2}{|c|}{$\begin{array}{c}95 \% \text { C.I. } \\
\text { for } \operatorname{Exp}(B)\end{array}$} \\
\hline & & & & & & & Lower & Upper \\
\hline Constant & .006 & .379 & .000 & 1 & .987 & 1.006 & & \\
\hline $\begin{array}{l}\text { Low } \\
\text { intelligence or } \\
\text { academic } \\
\text { achievement }\end{array}$ & .478 & .511 & .876 & 1 & .349 & 1.614 & .592 & 4.394 \\
\hline $\begin{array}{l}\text { Problems in } \\
\text { school }\end{array}$ & .830 & .529 & 2.456 & 1 & .117 & 2.293 & .812 & 6.472 \\
\hline $\begin{array}{l}\text { Antisocial } \\
\text { behaviour }\end{array}$ & .796 & .565 & 1.986 & 1 & .159 & 2.216 & .733 & 6.704 \\
\hline $\begin{array}{l}\text { Trauma, } \\
\text { neglect, or } \\
\text { abuse }\end{array}$ & 1.719 & 1.086 & 2.504 & 1 & .114 & 5.580 & .664 & 46.916 \\
\hline
\end{tabular}

other significant differences for risk factors occurring in adolescence for male patients who experienced an adverse event and those who did not.

Cross tabulation analyses of childhood and adolescent risk factors and adverse events for female patients are present in Tables 13 and 14, respectively. Similarly, for female patients, there were no significant differences for risk factors occurring in childhood for those who experienced 
Table 17

Logistic Regression of Childhood Risk Factors and Any Adverse Event for Female Patients

\begin{tabular}{|c|c|c|c|c|c|c|c|c|}
\hline \multirow[t]{2}{*}{ Predictor } & \multirow[t]{2}{*}{ B } & \multirow[t]{2}{*}{ S.E. } & \multirow[t]{2}{*}{ Wald } & \multirow[t]{2}{*}{$\mathrm{df}$} & \multirow[t]{2}{*}{ Sig. } & \multirow[t]{2}{*}{$\operatorname{Exp}(B)$} & \multicolumn{2}{|c|}{$\begin{array}{c}95 \% \text { C.I. } \\
\text { for } \operatorname{Exp}(\mathrm{B})\end{array}$} \\
\hline & & & & & & & Lower & Upper \\
\hline Constant & .560 & .362 & 2.391 & 1 & .122 & 1.750 & & \\
\hline $\begin{array}{l}\text { Trauma, abuse } \\
\text { or neglect }\end{array}$ & 1.145 & .860 & 1.817 & 1 & .178 & 3.143 & .594 & 16.616 \\
\hline
\end{tabular}

Table 18

Logistic Regression of Adolescent Risk Factors and Any Adverse Event for Female Patients

\begin{tabular}{lcccccccc}
\hline \multicolumn{1}{c}{ Predictor } & B & S.E. & Wald & df & Sig. & $\operatorname{Exp~(B)~}$ & \multicolumn{2}{c}{$\begin{array}{c}\text { 95\% C.I. } \\
\text { for Exp (B) }\end{array}$} \\
\hline $\begin{array}{l}\text { Constant } \\
\text { Low }\end{array}$ & .132 & .428 & .096 & 1 & .757 & 1.141 & & \\
$\begin{array}{l}\text { intelligence or } \\
\text { academic }\end{array}$ & .906 & .653 & 1.923 & 1 & .166 & 2.474 & .688 & 8.906 \\
$\begin{array}{l}\text { achievement } \\
\text { Substance use }\end{array}$ & .828 & .750 & 1.221 & 1 & .269 & 2.289 & .527 & 9.950 \\
\hline
\end{tabular}

an adverse event and those who did not. For risk factors occurring in adolescence, 22\% of female patients who experienced an adverse event experienced trauma, abuse, or neglect in adolescence, compared to $0 \%$ of female patients who did not experience an adverse event.

For male patients, attention-hyperactivity-impulsivity, antisocial behaviour, and broken home or frequent transitions were entered into the logistic regression for childhood predictors. The results are presented in Table 15. VIF for risk factors occurring in childhood ranged from 1.144 to 1.402 . This model was not significant, $X^{2}(3, \mathrm{~N}=100)=3.430, p=.330$. Low intelligence or academic achievement, problems at school, and trauma, abuse, or neglect were entered into the adolescent predictor model (see Table 16). VIF for adolescent predictors ranged from 1.046 to 1.900 . The overall model was significant, $X^{2}(3, \mathrm{~N}=100)=9.488, p<.05$. The 
Nagelkerke pseudo $\mathrm{R}^{2}$ statistic indicated that $13.8 \%$ of the variance in adverse events was accounted for by the predictors in the model. The model correctly classified $68.5 \%$ of cases. However, none of the predictors in the model was significant.

The only risk factor occurring in childhood that was entered into the model for female patients was trauma, abuse or neglect. The results are presented in Table 17. The overall model was not significant, $X^{2}(1, \mathrm{~N}=50)=2.110, p=.416$. Low intelligence or academic achievement in adolescence and substance use in adolescence were entered into the adolescent risk factor model for female patients (see Table 18). VIF for adolescent predictors ranged from 1.096 to 2.634. Trauma, abuse, or neglect occurring in adolescence could not be entered into the logistic regression, as one of the cells was a 0 (i.e., no female patients who did not have an adverse event experienced trauma, abuse, or neglect in adolescence). The overall model was also not significant, $X^{2}(2, \mathrm{~N}=50)=4.005, p=.135$.

\section{Supplementary Analyses}

Supplementary analyses were conducted in order to assess whether different childhood or adolescent risk factors predict specific adverse events, rather than all combined adverse events. Analyses were conducted on all adverse events that occurred in more than $10 \%$ of the sample, which included conflicts with staff or patients, medication nonadherence or refusal, verbal or physical violence, substance abuse relapses, being placed in seclusion, and being AWOL.

Two models containing risk factors occurring in childhood were significant. Problems in school, parental psychopathology, broken home, and trauma, abuse, or neglect predicted substance abuse relapses (Table 19), $X^{2}(4, \mathrm{~N}=150)=13.933, p<.05$. This model accounted for $19 \%$ of the variance in substance abuse relapses. Specifically, patients who experienced trauma, 
Table 19

Logistic Regression of Childhood Risk Factors and Substance Abuse Relapses for the Combined Sample

\begin{tabular}{|c|c|c|c|c|c|c|c|c|}
\hline \multirow[t]{2}{*}{ Predictor } & \multirow[t]{2}{*}{ B } & \multirow[t]{2}{*}{ S.E. } & \multirow[t]{2}{*}{ Wald } & \multirow[t]{2}{*}{$\mathrm{df}$} & \multirow[t]{2}{*}{ Sig. } & \multirow{2}{*}{$\begin{array}{c}\operatorname{Exp} \\
\text { (B) }\end{array}$} & \multicolumn{2}{|c|}{$\begin{array}{c}95 \% \text { C.I. } \\
\text { for } \operatorname{Exp}(B)\end{array}$} \\
\hline & & & & & & & Lower & Upper \\
\hline Constant & -2.66 & .493 & 29.038 & 1 & .000 & .070 & & \\
\hline $\begin{array}{l}\text { Problems in } \\
\text { school }\end{array}$ & .312 & .714 & .190 & 1 & .663 & 1.366 & .337 & 5.534 \\
\hline $\begin{array}{l}\text { Parental } \\
\text { psychopathology } \\
\text { or substance use }\end{array}$ & .676 & .660 & 1.049 & 1 & .306 & 1.967 & .539 & 7.174 \\
\hline Broken home & .656 & .543 & 1.459 & 1 & .227 & 1.927 & .665 & 5.585 \\
\hline $\begin{array}{l}\text { Trauma, abuse, } \\
\text { or neglect }\end{array}$ & 1.504 & .541 & 7.736 & 1 & .005 & 4.502 & 1.559 & $12.996 *$ \\
\hline
\end{tabular}

Table 20

Logistic Regression of Childhood Risk Factors and Medication Nonadherence or Refusal for the Combined Sample

\begin{tabular}{|c|c|c|c|c|c|c|c|c|}
\hline \multirow[t]{2}{*}{ Predictor } & \multirow[t]{2}{*}{ B } & \multirow[t]{2}{*}{ S.E. } & \multirow[t]{2}{*}{ Wald } & \multirow[t]{2}{*}{$\mathrm{df}$} & \multirow[t]{2}{*}{ Sig. } & \multirow[t]{2}{*}{$\operatorname{Exp}(B)$} & \multicolumn{2}{|c|}{$\begin{array}{c}95 \% \text { C.I. } \\
\text { for } \operatorname{Exp}(\mathrm{B})\end{array}$} \\
\hline & & & & & & & Lower & Upper \\
\hline Constant & -1.03 & .269 & 14.635 & 1 & .000 & .358 & & \\
\hline $\begin{array}{l}\text { Problems in } \\
\text { school }\end{array}$ & -1.33 & .775 & 2.947 & 1 & .086 & .265 & .058 & 1.207 \\
\hline $\begin{array}{l}\text { Antisocial } \\
\text { behaviour }\end{array}$ & .813 & .540 & 2.267 & 1 & .132 & 2.255 & .782 & 6.502 \\
\hline $\begin{array}{l}\text { Trauma, abuse, } \\
\text { or neglect }\end{array}$ & 1.094 & .437 & 6.273 & 1 & .012 & 2.986 & 1.268 & $7.027 *$ \\
\hline
\end{tabular}

abuse, or neglect in childhood were significantly more likely to experience substance abuse relapses $(p<.05)$. Additionally, problems in school, antisocial behaviour, and trauma, neglect, or abuse predicted medication nonadherence or refusal (Table 20$), X^{2}(3, \mathrm{~N}=150)=10.443, p=$ .015. This model accounted for $12 \%$ of the variance in medication nonadherence or refusal. Again, patients who experienced trauma, abuse, or neglect in childhood had significantly greater 
Table 21

Logistic Regression of Childhood Risk Factors and Placement in Seclusion for the Combined Sample

\begin{tabular}{lcccccccc}
\hline \multicolumn{1}{c}{ Predictor } & B & S.E. & Wald & df & Sig. & Exp (B) & \multicolumn{2}{c}{$\begin{array}{c}\text { 95\% C.I. } \\
\text { for Exp (B) }\end{array}$} \\
\hline $\begin{array}{l}\text { Constant } \\
\begin{array}{l}\text { Antisocial } \\
\text { behaviour }\end{array}\end{array}$ & -1.35 & .342 & 15.509 & 1 & .000 & .260 & & Lower \\
$\begin{array}{l}\text { Parental } \\
\text { psychopper } \\
\text { or substance use }\end{array}$ & 1.051 & .554 & 3.597 & 1 & .058 & 2.859 & .965 & 8.467 \\
\hline
\end{tabular}

Table 22

Logistic Regression of Childhood Risk Factors and Verbal or Physical Violence for the Combined Sample

\begin{tabular}{|c|c|c|c|c|c|c|c|c|}
\hline \multirow[t]{2}{*}{ Predictor } & \multirow[t]{2}{*}{ B } & \multirow[t]{2}{*}{ S.E. } & \multirow[t]{2}{*}{ Wald } & \multirow[t]{2}{*}{ df } & \multirow[t]{2}{*}{ Sig. } & \multirow[t]{2}{*}{$\operatorname{Exp}(B)$} & \multicolumn{2}{|c|}{$\begin{array}{c}95 \% \text { C.I. } \\
\text { for } \operatorname{Exp}(\mathrm{B})\end{array}$} \\
\hline & & & & & & & Lower & Upper \\
\hline Constant & -.638 & .228 & 7.816 & 1 & .005 & .528 & & \\
\hline $\begin{array}{l}\text { Antisocial } \\
\text { behaviour }\end{array}$ & .858 & .456 & 3.541 & 1 & .060 & 2.358 & .965 & 5.761 \\
\hline $\begin{array}{l}\text { Parental } \\
\text { psychopathology } \\
\text { or substance use }\end{array}$ & -1.10 & .625 & 3.082 & 1 & .079 & .334 & .098 & 1.136 \\
\hline
\end{tabular}

odds of also not adhering to or refusing medications $(p<.05)$.

Childhood risk factors did not predict being placed in seclusion (Table 21), $X^{2}(2, \mathrm{~N}=$ $150)=5.133, p=.077$, verbal or physical violence $($ Table 22$), X^{2}(2, \mathrm{~N}=150)=5.938, p=.051$, conflict with staff or patients (Table 23$), X^{2}(5, \mathrm{~N}=150)=11.022, p=.051$, or being AWOL (Table 24), $X^{2}(5, \mathrm{~N}=150)=9.236, p=.100$.

For risk factors occurring in adolescence, three models were significant. As a model, low intelligence or academic achievement, antisocial behaviour, and trauma, abuse, or neglect in 
Table 23

Logistic Regression of Childhood Risk Factors and Conflict with Staff or Patients for the Combined Sample

\begin{tabular}{|c|c|c|c|c|c|c|c|c|}
\hline \multirow[t]{2}{*}{ Predictor } & \multirow[t]{2}{*}{ B } & \multirow[t]{2}{*}{ S.E. } & \multirow[t]{2}{*}{ Wald } & \multirow[t]{2}{*}{ df } & \multirow[t]{2}{*}{ Sig. } & \multirow[t]{2}{*}{$\operatorname{Exp}(\mathrm{B})$} & \multicolumn{2}{|c|}{$\begin{array}{c}95 \% \text { C.I. } \\
\text { for } \operatorname{Exp}(\mathrm{B})\end{array}$} \\
\hline & & & & & & & Lower & Upper \\
\hline Constant & -1.24 & .316 & 15.430 & 1 & .000 & .290 & & \\
\hline $\begin{array}{l}\text { Low intelligence } \\
\text { or academic } \\
\text { achievement }\end{array}$ & .521 & .414 & 1.583 & 1 & .208 & 1.684 & .748 & 3.795 \\
\hline $\begin{array}{l}\text { Antisocial } \\
\text { behaviour }\end{array}$ & .892 & .450 & 3.937 & 1 & .047 & 2.441 & 1.011 & 5.895 \\
\hline Health problems & .359 & .426 & .713 & 1 & .398 & 1.433 & .622 & 3.299 \\
\hline Broken home & .281 & .375 & .562 & 1 & .454 & 1.324 & .635 & 2.759 \\
\hline $\begin{array}{l}\text { Trauma, abuse, } \\
\text { or neglect }\end{array}$ & .363 & .412 & .775 & 1 & .379 & 1.437 & .641 & 3.222 \\
\hline
\end{tabular}

Table 24

Logistic Regression of Childhood Risk Factors and being AWOL for the Combined Sample

\begin{tabular}{|c|c|c|c|c|c|c|c|c|}
\hline \multirow[t]{2}{*}{ Predictor } & \multirow[t]{2}{*}{ B } & \multirow[t]{2}{*}{ S.E. } & \multirow[t]{2}{*}{ Wald } & \multirow[t]{2}{*}{$\mathrm{df}$} & \multirow[t]{2}{*}{ Sig. } & \multirow[t]{2}{*}{$\operatorname{Exp}(B)$} & \multicolumn{2}{|c|}{$\begin{array}{c}95 \% \text { C.I. } \\
\text { for } \operatorname{Exp}(\mathrm{B})\end{array}$} \\
\hline & & & & & & & Lower & Upper \\
\hline Constant & -2.26 & .437 & 26.646 & 1 & .000 & .105 & & \\
\hline $\begin{array}{l}\text { Low intelligence } \\
\text { or academic } \\
\text { achievement }\end{array}$ & .766 & .631 & 1.473 & 1 & .225 & 2.150 & .624 & 7.405 \\
\hline $\begin{array}{l}\text { Antisocial } \\
\text { behaviour }\end{array}$ & .356 & .697 & .260 & 1 & .610 & 1.427 & .364 & 5.599 \\
\hline Health problems & -1.85 & 1.089 & 2.875 & 1 & .090 & .158 & .019 & 1.334 \\
\hline Broken home & .248 & .787 & .099 & 1 & .753 & 1.282 & .274 & 5.997 \\
\hline $\begin{array}{l}\text { Trauma, abuse, } \\
\text { or neglect }\end{array}$ & .728 & .630 & 1.334 & 1 & .248 & 2.070 & .602 & 7.116 \\
\hline
\end{tabular}

adolescence significantly predicted being placed in seclusion (Table 25$), X^{2}(3, \mathrm{~N}=150)=9.125$, $p<.05$, accounting for $14 \%$ of the variance. However, none of the individual predictors was significant. Low intelligence or academic achievement, problems in school, and antisocial 
Table 25

Logistic Regression of Adolescent Risk Factors and Placement in Seclusion for the Combined Sample

\begin{tabular}{|c|c|c|c|c|c|c|c|c|}
\hline \multirow[t]{2}{*}{ Predictor } & \multirow[t]{2}{*}{ B } & \multirow[t]{2}{*}{ S.E. } & \multirow[t]{2}{*}{ Wald } & \multirow[t]{2}{*}{ df } & \multirow[t]{2}{*}{ Sig. } & \multirow[t]{2}{*}{$\operatorname{Exp}(B)$} & \multicolumn{2}{|c|}{$\begin{array}{c}95 \% \text { C.I. } \\
\text { for } \operatorname{Exp}(\mathrm{B})\end{array}$} \\
\hline & & & & & & & Lower & Upper \\
\hline Constant & -1.79 & .502 & 12.714 & 1 & .000 & .167 & & \\
\hline $\begin{array}{l}\text { Low intelligence } \\
\text { or academic } \\
\text { achievement }\end{array}$ & .399 & .589 & .459 & 1 & .498 & 1.491 & .469 & 4.734 \\
\hline $\begin{array}{l}\text { Antisocial } \\
\text { behaviour }\end{array}$ & .928 & .566 & 2.689 & 1 & .101 & 2.531 & .834 & 7.678 \\
\hline $\begin{array}{l}\text { Trauma, abuse, } \\
\text { or neglect }\end{array}$ & -2.00 & 1.076 & 3.458 & 1 & .063 & .135 & .016 & 1.114 \\
\hline
\end{tabular}

Table 26

Logistic Regression of Adolescent Risk Factors and Verbal or Physical Violence for the Combined Sample

\begin{tabular}{lcccccccc}
\hline \multicolumn{1}{c}{ Predictor } & B & S.E. & Wald & df & Sig. & Exp (B) & \multicolumn{2}{c}{$\begin{array}{c}\text { 95\% C.I. } \\
\text { for Exp (B) }\end{array}$} \\
\hline $\begin{array}{l}\text { Constant } \\
\begin{array}{l}\text { Low intelligence } \\
\text { or academic } \\
\text { achievement }\end{array}\end{array}$ & -1.44 & .331 & 18.903 & 1 & .000 & .237 & & Lower \\
$\begin{array}{l}\text { Problems in } \\
\text { school }\end{array}$ & .729 & .411 & 2.010 & 1 & .156 & 1.790 & .800 & 4.003 \\
$\begin{array}{l}\text { Antisocial } \\
\text { behaviour }\end{array}$ & .261 & .431 & .367 & 1 & .545 & 1.298 & .558 & 3.020 \\
\hline
\end{tabular}

behaviour in adolescence predicted verbal or physical violence (Table 26$), X^{2}(3, \mathrm{~N}=150)=$ $10.602, p<.05$. This model accounted for $10 \%$ of the variance in verbal or physical violence. Again, none of the predictors was significant. Problems in school, antisocial behaviour, substance use, broken home, and trauma, abuse, or neglect in adolescence predicted substance abuse relapses (Table 27), $X^{2}(5, \mathrm{~N}=150)=21.556, p<.05$. This model accounted for $25 \%$ of 
Table 27

Logistic Regression of Adolescent Risk Factors Substance Abuse Relapses for the Combined Sample

\begin{tabular}{lcccccccc}
\hline \multicolumn{1}{c}{ Predictor } & B & S.E. & Wald & df & Sig. & $\begin{array}{c}\text { Exp } \\
\text { (B) }\end{array}$ & & \multicolumn{2}{c}{$\begin{array}{c}\text { 95\% C.I. } \\
\text { for Exp (B) }\end{array}$} \\
\hline $\begin{array}{l}\text { Constant } \\
\begin{array}{l}\text { Problems in } \\
\text { school }\end{array}\end{array}$ & -3.26 & .568 & 32.879 & 1 & .000 & .038 & & Upper \\
$\begin{array}{l}\text { Antisocial } \\
\text { behaviour }\end{array}$ & 1.337 & .626 & 4.560 & 1 & .033 & 3.807 & 1.116 & $12.985^{*}$ \\
$\begin{array}{l}\text { Substance use } \\
\begin{array}{l}\text { Broken home } \\
\text { Trauma, abuse, }\end{array}\end{array}$ & 1.095 & .615 & .024 & 1 & .878 & 1.099 & .330 & 3.668 \\
or neglect & 1.074 & .623 & 2.680 & 1 & .102 & 2.771 & .818 & 9.391 \\
\hline
\end{tabular}

Table 28

Logistic Regression of Adolescent Risk Factors and being AWOL for the Combined Sample

\begin{tabular}{lcccccccc}
\hline \multicolumn{1}{c}{ Predictor } & B & S.E. & Wald & df & Sig. & Exp (B) & \multicolumn{2}{c}{$\begin{array}{c}\text { 95\% C.I. } \\
\text { for Exp (B) }\end{array}$} \\
\hline $\begin{array}{l}\text { Constant } \\
\begin{array}{l}\text { Low intelligence } \\
\text { or academic } \\
\text { achievement }\end{array}\end{array}$ & -1.55 & .332 & 21.908 & 1 & .000 & .212 & & Lower \\
\hline
\end{tabular}

the variance in substance abuse relapses. Patients who experienced problems at school in adolescence had significantly greater odds of substance abuse relapses $(p<.05)$.

Risk factors occurring in adolescence did not significantly predict being AWOL (Table $28), X^{2}(1, \mathrm{~N}=150)=1.579, p=.209$ or conflict with staff or patients (Table 29$), X^{2}(5, \mathrm{~N}=150)$ $=8.815, p=.117$. 
Table 29

Logistic Regression of Adolescent Risk Factors and Conflict with Staff or Patients for the Combined Sample

\begin{tabular}{|c|c|c|c|c|c|c|c|c|}
\hline \multirow[t]{2}{*}{ Predictor } & \multirow[t]{2}{*}{ B } & \multirow{2}{*}{ S.E. } & \multirow{2}{*}{ Wald } & \multirow[t]{2}{*}{ df } & \multirow{2}{*}{ Sig. } & \multirow{2}{*}{$\operatorname{Exp}(B)$} & \multicolumn{2}{|c|}{$\begin{array}{c}95 \% \text { C.I. } \\
\text { for } \operatorname{Exp}(\mathrm{B})\end{array}$} \\
\hline & & & & & & & Lower & Upper \\
\hline Constant & -1.26 & .358 & 12.343 & 1 & .000 & .285 & & \\
\hline $\begin{array}{l}\text { Low intelligence } \\
\text { or academic } \\
\text { achievement }\end{array}$ & .513 & .419 & 1.503 & 1 & .220 & 1.671 & .735 & 3.797 \\
\hline $\begin{array}{l}\text { Problems in } \\
\text { school }\end{array}$ & -.063 & .483 & .017 & 1 & .895 & .938 & .364 & 2.417 \\
\hline $\begin{array}{l}\text { Antisocial } \\
\text { behaviour }\end{array}$ & .477 & .448 & 1.134 & 1 & .287 & 1.611 & .670 & 3.873 \\
\hline Substance use & .130 & .430 & .092 & 1 & .761 & 1.139 & .491 & 2.645 \\
\hline $\begin{array}{l}\text { Trauma, abuse, } \\
\text { or neglect }\end{array}$ & 1.002 & .542 & 3.416 & 1 & .065 & 2.725 & .941 & 7.889 \\
\hline
\end{tabular}




\section{Discussion}

Taking an RFR approach, this thesis examined whether risk factors occurring in childhood and adolescence predicted adverse events in a sample of 150 adult forensic psychiatric patients. The purpose of this thesis was to identify whether developmental risk factors for offending that have been observed as significant predictors of adverse outcomes in correctional populations predicted adverse events in a forensic psychiatric population. The present study contributes to better understanding the development of negative behaviours across the lifespan in this population.

The first research question assessed the prevalence of different adverse events in the sample. Overall, $68 \%$ of the sample experienced at least one adverse event, and there was no difference between the prevalence of any adverse event for male and female patients. The four most common specific adverse events were conflicts with staff or patients (35\%), verbal or physical violence (33\%), medication refusal or noncompliance (33\%) and substance abuse relapses $(17 \%)$. The 1-year prevalence of verbal or physical violence is similar to that found in

previous research (Hoptman et al., 1999; Linhorst \& Scott, 2004; Penney et al., 2016). There was a lower rate of hospital re-admission in the combined, male and female sample (12\%) than has been found in previous work by Penney et al. (2016), who found that $28 \%$ of their sample was re-admitted to hospital following discharge. However, for this thesis, the database used for obtaining outcomes did not include a variable indicating which patients were at risk of a readmission at the beginning of the coded clinical year. Patient status was coded at the time of the ORB hospital report, which was written for each patient at the end of a clinical year. Thus, the percentage of re-admissions to hospital is in reality larger than $12 \%$, as some patients were likely inpatient throughout the entire 12-month coding period, and so technically could not have been re-admitted; yet these patients were still included in the prevalence calculation. Only three 
patients $(2 \%)$ obtained new charges during the coded clinical year. This 1-year prevalence is in accordance with the findings of Penney et al. (2016) and De Vries Robbé et al. (2015).

Female patients were more likely to experience several adverse events compared to male patients. Specifically, female patients were more likely to experience restraint use, suicidality or self-harm, and readmission to hospital than male patients. These findings may be of clinical relevance when managing risk and planning clinical care for female patients.

In order to answer the second and third research questions, risk factors were separated based on their age of occurrence (childhood or adolescence). The results of the analyses provided partial support for the hypotheses. Contrary to expectations, the model with childhood risk factors was not significant. However, the model containing risk factors occurring in adolescence significantly predicted adverse events in the combined sample. This finding is in accordance with the longitudinal law, which proposes that the longer the period of time between the predictor and the event, the poorer the prediction (Clarke \& Clarke, 1984). However, in supplementary analyses for specific adverse events, childhood risk factors did predict substance abuse relapses and medication nonadherence or refusal. Thus, some childhood risk factors did predict certain adverse events, but it is possible that combining all adverse events for main analyses prevented these associations from emerging.

Patients who experienced trauma, abuse, or neglect in adolescence had over 8 times greater odds of experiencing an adverse event over the coded clinical year than patients who had not experienced this risk factor as an adolescent. These odds should be interpreted with caution, however, as 95\% confidence intervals were very large. This finding is consistent with Hoptman et al. (1999) who found that physical assault experienced in "childhood," but not sexual assault, predicted inpatient assault in a sample of forensic patients. Note that these authors did not specify an age range for the experience of the physical or sexual assault. Therefore, it is possible 
that this childhood risk factor could have referred more generally to a developmental risk factor and included adolescence.

Additionally, results are also consistent with the work of Blomhoff et al. (1990), which found that psychiatric inpatients who engaged in physical aggression were significantly more likely to have experienced violence between parents in youth, than those who were not physically aggressive. In this thesis, witnessing physical violence was included as an indicator of experiencing trauma, abuse or neglect. Bruce and Laporte (2015) also found that psychiatric patients who had experiences of early trauma had greater odds of engaging in inpatient violence than those who did not experience trauma. The authors suggested that because early traumatic experiences may influence neurodevelopment (Schore, 2002), these experiences may lead to early-onset antisocial behaviour, increasing the odds of violence in adulthood. Bruce and Laporte (2015) found that individuals who experienced early trauma had greater odds of exhibiting earlyonset antisocial behaviour, and greater odds of engaging in inpatient violence. In the present study, however, antisocial behaviour in childhood or adolescence was not predictive of verbal or physical violence or any other specific adverse event, and was, in fact, negatively associated with adverse events when controlling for total score on the HCR-20. In all, the finding that trauma, abuse, or neglect predicted adverse events, is largely consistent with previous work in forensic and psychiatric populations.

Contrary to findings by Harris et al. (1993), separation from parents (in this study conceptualized as having a broken home or involvement in alternative care) or problems in elementary school did not predict adverse events. However, Harris et al. (1993) examined predictors of recidivism in a forensic psychiatric population, and it is possible that different risk factors predict different adverse events (as was shown in the results from supplementary analyses). In the study sample, rates of recidivism were extremely low, and it was not possible to specifically analyse predictors of recidivism. 
Contrary to findings in offender populations (Moffitt, 1993) and psychiatric populations (Bruce \& Laporte, 2015), an early propensity to engage in antisocial behaviour was not predictive of all adverse events combined in this forensic psychiatric sample, nor was it predictive of any specific adverse events. This finding is in accordance with the typology proposed by Hodgins (2008), which states that the majority of offenders with schizophrenia do not have a childhood history of antisocial behaviour.

In order to answer the fourth research question, a hierarchical logistic regression was conducted, entering HCR-20 total score in the first block, and risk factors occurring in adolescence in the second block. As HCR-20 total score increased by one unit, the odds of experiencing an adverse event increased by 1.4. Score on the HCR-20 accounted for a larger percentage of variance in adverse outcomes than any of the models with risk factors occurring in adolescence. This finding is not unexpected, as the HCR-20 has been found to predict inpatient aggression in forensic populations (e.g., Hogan \& Olver, 2016). However, in the present study, the HCR-20 predicted any adverse outcome, not limited to violence or aggression, suggesting that the HCR-20 may be useful in predicting a variety of adverse events. Unexpectedly, when HCR-20 was entered into the first block, antisocial behaviour in adolescence negatively predicted adverse events. Thus, patients who engaged in antisocial behaviour in adolescence had lower odds of experiencing an adverse event. The direction of this relationship was not expected, given previous work by (Bruce \& Laporte, 2015), and may be due to a suppressor effect. It is possible that the item in the HCR-20 assessing previous violence acted as a suppressor, resulting in the negative beta for antisocial behaviour.

To test the fifth research question, male and female patients were analyzed separately. Neither childhood nor adolescent risk factor models predicted adverse events in female patients. This is possibly due to the small sample size of females. For male patients, as in the combined sample, the model containing only risk factors occurring in childhood did not predict adverse 
events. However, the model containing risk factors occurring in adolescence did predict adverse events, yet none of the individual predictors was significant. The lack of significance for individual predictors may be due to the small sample size or the low base rates of the risk factors.

The objective of this thesis was to use a developmental RFR framework to identify childhood or adolescent risk factors that predicted adverse events in a forensic psychiatric sample in order to understand how early development may influence outcomes in adulthood. Overall, risk factors occurring in adolescence were found to predict adverse events.

Supplementary analyses also showed that childhood risk factors predict substance abuse relapses and medication nonadherence or refusal. However, the results of this study do not allow for understanding how these risk factors are related to adverse events. This thesis provided preliminary evidence of an association between developmental variables and adult events in a forensic psychiatric sample. The main finding that trauma, abuse, or neglect predicted adverse events was consistent with previous work in forensic and forensic psychiatric samples (e.g., Blomhoff et al., 1990; Bruce \& Laporte, 2015; Hoptman et al., 1999). In addition, this study also showed that adolescent risk factors in general can predict adverse events. Thus, there is evidence that experiences during development are related to adverse events in adulthood for patients found NCRMD. It is not possible to say, however, whether these risk factors are causally linked to adverse events in adulthood.

\section{Limitations}

The present study is not without limitations, which need to be acknowledged. While the patient's location at time of the ORB hospital report (the patient status at the end of the coded clinical year) was noted in the database containing information regarding adverse events, it was not possible to not know whether the adverse event occurred in an inpatient or outpatient setting. Adverse events may have occurred while the individual was on a community pass, even though they were considered an inpatient over the clinical year. Furthermore, an individual may have 
been re-admitted to hospital over the course of the year and thereby may have had adverse events occurring both in hospital and in the community. The inability to identify where adverse events happened necessarily resulted in an underestimation of the prevalence of certain adverse events that can only happen in hospital (i.e., being placed in seclusion) or those that can only happen if an individual is an outpatient (i.e., hospital re-admission). Additionally, given this lack of information, it was not possible to analyze whether developmental risk factors differentially predicted events occurring in hospital versus events occurring in the community.

ORB hospital reports contained little to no information regarding protective factors in childhood or adolescence or positive events in adulthood. Thus, it was not possible to assess the effect of protective factors earlier in life on adverse events. Furthermore, it was not possible to provide the prevalence of positive events in this sample, and to assess the association between developmental risk factors and positive events.

Developmental information in ORB hospital reports was largely retrospective, recalled by patients and/or their family members. In some rare cases, developmental history was obtained from official records, such as medical records from the patient's childhood or adolescence. As the majority of developmental information was recalled by patients and families many years after occurrence, it is likely that this information is to some extent incomplete or inaccurate. Of note, it is possible that risk factors occurring in childhood were more poorly recalled than risk factors occurring in adolescence due to limitations of memory. Furthermore, there may have been better records kept of risk factors occurring in adolescence versus in childhood, especially for antisocial behaviour resulting in involvement with the criminal justice system. However, a prospective longitudinal study assessing the development of individuals found NCRMD would be highly intensive, given that forensic psychiatric populations are relatively small proportions of the total population. Such a study would require following an extremely large number of children over decades and separately analyzing those who ended up being found NCRMD. 
ORB hospital reports rarely explicitly indicated if a developmental risk factor was absent. Most often, only the presence of a risk factor was noted. Thus, during coding, if a developmental risk factor was not present in the report, it was assumed to have not occurred. This interpretation could have been problematic, as it is not possible to know if the lack of a risk factor noted in a report meant that the interviewer inquired about the risk factor and the patient denied experiencing it, or if the interviewer did not ask about that particular risk factor. However, without interpreting absent risk factors as not having occurred, it would not have been possible to analyze the coded data, as the majority would have been considered missing.

Overall, the base rates of some risk factors, especially those occurring in childhood, were low. With the limitations of retrospective recall of childhood and adolescence, and the possibility that not all coded risk factors were systematically assessed for the purpose of the ORB hospital report, it is likely that the prevalence of these risk factors in a forensic psychiatric sample was underestimated. Consequently, it is possible that in conjunction with the sample size, the low base rates of risk factors may have contributed to nonsignificant findings.

Several risk factors occurring in childhood and adolescence had base rates below 10\%, preventing inclusion in analyses. In terms of childhood risk factors, these included substance use, family criminal activity and involvement in alternative care. Additionally, for female patients, problems in school, and hyperactivity-impulsivity-attention in childhood occurred in less than $10 \%$ of the sample. In terms of risk factors occurring in adolescence, hyperactivity-impulsivityattention, health problems, family criminal activity, parental psychopathology or substance use, and involvement in alternative care occurred in less than $10 \%$ of the sample. While it is possible that these risk factors were so rare that they are unlikely to be an important variable in predicting adverse events, it is also possible that interviews conducted for ORB hospital reports did not systematically or consistently ask about these variables. Future research is required to assess whether these risk factors may predict adverse events. 
Findings from this thesis indicate that any experiences of adolescent trauma, neglect, or abuse predict a variety of adverse events in a forensic psychiatric sample. However, given the small base rates of each specific type of trauma, abuse, or neglect, more detailed analyses regarding which of these predict which adverse event were not possible. In supplementary analyses of predictors of specific adverse events, trauma, abuse, or neglect in adolescence did not significantly predict any specific outcomes; however, trauma, abuse, or neglect in childhood did significantly predict substance abuse relapses and medication nonadherence or refusal. These findings suggest that trauma, abuse, or neglect in childhood may also be associated with different adverse events in adulthood in an NCRMD sample. It is important to note that supplementary analyses were done on adverse events that occurred in less than $35 \%$ of the sample; thus, trauma, abuse, or neglect in adolescence may not have emerged as a predictor simply due to low base rates and subsequent low power to detect effects.

Due to the exploratory nature of this study, multiple comparisons were conducted using chi-square analyses, resulting in an increased risk of Type I error. Adjustments were not made to p-values to account for multiple comparisons; therefore, significant findings should be interpreted with caution. However, Cramèr's phi coefficients were calculated for effect size. In general, effect sizes for the relationship between childhood and adolescent risk factors and adverse events were weak to moderate (Rea \& Parker, 2005), ranging from $\phi=.169$ to $\phi=.280$.

Multicollinearity was assessed for all predictors occurring in childhood or adolescence. VIFs were below values indicating potentially problematic multicollinearity (Akinwande et al., 2015), indicating that coefficients for individual predictors were not drastically affected by strong correlations between predictors. It is suspected that instances where there were significant models that lacked significant predictors may have occurred due to lack of power (as a result of a small sample size or low base rates for predictors). Additionally, it is possible that none of the risk factors in these models individually predicted adverse events; but taken together, they did. 


\section{Future Directions}

Future research should continue to include female patients in the sample and assess whether there are developmental differences between male and female forensic psychiatric patients that would require separate analyses of patients by gender. It is important to consider whether there is a theoretical or empirical reason to exclude cases based on gender, rather than excluding individuals because we do not yet know whether males and females differ. Future research would benefit from data collection across institutions to ensure an adequate sample size of female participants. Unfortunately, this thesis was not able to analyze whether male and female patients differed on developmental risk factors which predicted adverse events, as the combination of low base rates of risk factors and a small sample size resulted in an underpowered study.

Future studies may seek to understand how trauma, abuse, or neglect in childhood or adolescence is related to adverse events in forensic psychiatric patients. Several studies have found that experiences of trauma, abuse, or neglect during childhood or adolescence is more common in forensic and psychiatric patients that experience adverse events (Blomhoff et al., 1990; Bruce \& Laporte, 2015; Hoptman et al., 1999). However, it is not yet known which forms of trauma, abuse, or neglect predict adverse events. Furthermore, it is not known how this risk factor is related to adverse events. Future studies may examine mediation or moderation models to better understand this relationship.

Lastly, future work would benefit from the assessment of protective factors in addition to risk factors. Protective factors may moderate the relationship between risk factors and adverse events, such that those who have experienced both risk and protective factors in childhood or adolescence, may not have greater odds of experiencing an adverse event, while those who experienced only risk factors, may have greater odds of experiencing an adverse event. 
Assessing only risk factors may result in an incomplete understanding of development across the lifespan for individuals found NCRMD. 


\section{Appendix}

ID:

Date:

Childhood Risk Factor Coding Scheme

Individual factors

$\underline{\text { Yes/Suspected Unknown }} \underline{\text { No }}$

Age

1. Low intelligence or poor academic achievement

\begin{tabular}{|l|l|l|l|l|}
\hline Low intelligence & & & & \\
\hline Learning disability & & & & \\
\hline $\begin{array}{l}\text { Enrolled in special } \\
\text { education classes }\end{array}$ & & & & \\
\hline $\begin{array}{l}\text { General academic-related } \\
\text { difficulties }\end{array}$ & & & & \\
\hline $\begin{array}{l}\text { Failed or repeated grade } \\
\text { grade: }\end{array}$ & & & & \\
\hline $\begin{array}{l}\text { Dropped out of school (last } \\
\text { grade completed: }\end{array}$ & & & & \\
\hline Present (1) or Absent (0) & & & \\
\hline
\end{tabular}

Notes:

2. Problems at school

\begin{tabular}{|l|l|l|l|l|}
\hline $\begin{array}{l}\text { Lack of academic } \\
\text { motivation or interest }\end{array}$ & & & & \\
\hline Truant & & & & \\
\hline Suspended & & & & \\
\hline Expelled & & & & \\
\hline Present (1) or Absent (0) & & & \\
\hline
\end{tabular}

Notes: 
3. Hyperactivity-impulsivity-inattention

\begin{tabular}{|l|l|l|l|l|}
\hline $\begin{array}{l}\text { Attention or concentration } \\
\text { difficulties/easily distracted }\end{array}$ & & & & \\
\hline Restless & & & & \\
\hline Cannot wait or take turns & & & & \\
\hline $\begin{array}{l}\text { Hyperactive/very } \\
\text { active/energetic }\end{array}$ & & & & \\
\hline Difficulty planning ahead & & & & \\
\hline ADD diagnosis & & & & \\
\hline ADHD diagnosis & & & & \\
\hline Present (1) or Absent $(0)$ & & & & \\
\hline
\end{tabular}

Notes:

\section{Antisocial behaviour}

\begin{tabular}{|l|l|l|l|l|}
\hline $\begin{array}{l}\text { Uses inappropriate } \\
\text { language (e.g., swearing, } \\
\text { sexual talk) }\end{array}$ & & & & \\
\hline $\begin{array}{l}\text { Defiant towards set rules or } \\
\text { authority figures }\end{array}$ & & & & \\
\hline Quick to anger & & & & \\
\hline Temper tantrums & & & & \\
\hline Verbally aggressive & & & & \\
\hline Physically aggressive & & & & \\
\hline Sexually precocious & & & & \\
\hline $\begin{array}{l}\text { Engaged in inappropriate } \\
\text { sexual behaviour }\end{array}$ & & & & \\
\hline Lying & & & \\
\hline Manipulative & & & \\
\hline
\end{tabular}




\begin{tabular}{|l|l|l|l|l|}
\hline & & & & \\
\hline Runs away & & & & \\
\hline Harmful toward animals & & & & \\
\hline $\begin{array}{l}\text { Vandalized (e.g., destroyed } \\
\text { property, graffiti) }\end{array}$ & & & & \\
\hline Stealing & & & & \\
\hline $\begin{array}{l}\text { Break and enter (e.g., } \\
\text { buildings, cars) }\end{array}$ & & & & \\
\hline Fire setting behaviour & & & & \\
\hline Gang member & & & & \\
\hline $\begin{array}{l}\text { Poor behaviour not } \\
\text { specified }\end{array}$ & & & & \\
\hline Shallow affect & & & & \\
\hline Lacks empathy & & & & \\
\hline Lacks remorse or guilt & & & \\
\hline Present (1) or Absent (0) & & & & \\
\hline
\end{tabular}

Notes:

\section{Alcohol and/or drug use}

\begin{tabular}{|l|l|l|l|}
\hline Alcohol & & & \\
\hline Hallucinogens (e.g., & & & \\
marijuana, psilocybin, LSD, & & & \\
MDMA, & & & \\
ketamine, mescaline, salvia, & & & \\
PCP) & & & \\
\hline Stimulants (e.g., cocaine, & & & \\
crack cocaine, & & & \\
amphetamine, & & & \\
methamphetamine, & & & \\
methylphenidate, & & & \\
dexedrine) & & & \\
\hline
\end{tabular}




\begin{tabular}{|l|l|l|l|l|}
\hline $\begin{array}{l}\text { Opiates (e.g., oxycontin, } \\
\text { percocet, codeine, } \\
\text { morphine, heroin, opium, } \\
\text { methadone) }\end{array}$ & & & & \\
\hline $\begin{array}{l}\text { Other depressants (e.g., } \\
\text { barbiturates, } \\
\text { benzodiazepines, GHB) }\end{array}$ & & & & \\
\hline Drugs unspecified & & & & \\
\hline Present (1) or Absent (0) & & & & \\
\hline
\end{tabular}

Notes:

\section{Health problems}

\begin{tabular}{|l|l|l|l|l|}
\hline $\begin{array}{l}\text { Traumatic Head Injury } \\
\text { (type: }\end{array}$ & & & & \\
\hline Seizure(s) & & & & \\
\hline $\begin{array}{l}\text { Invasive surgery } \\
\text { (specify: }\end{array}$ & & & & \\
\hline Early ear infections & & & & \\
\hline Enuresis & & & & \\
\hline Encopresis & & & & \\
\hline Obesity & & & & \\
\hline Hygiene problems & & & & \\
\hline $\begin{array}{l}\text { Other health problem(s) } \\
\text { (specify: }\end{array}$ & & & & \\
\hline Present (1) or Absent (0) & & & & \\
\hline
\end{tabular}

Notes: 


\section{Family factors}

\section{Criminal family members}

\begin{tabular}{|l|l|l|l|l|}
\hline Criminal mother & & & & \\
\hline Criminal father & & & & \\
\hline Criminal sibling & & & & \\
\hline Present (1) or Absent (0) & & & \\
\hline
\end{tabular}

Notes:

8. Parental psychopathology

\begin{tabular}{|l|l|l|l|l|}
\hline $\begin{array}{l}\text { Mental health difficulties - } \\
\text { mother }\end{array}$ & & & \\
\hline $\begin{array}{l}\text { Mental health difficulties - } \\
\text { father }\end{array}$ & & & & \\
\hline $\begin{array}{l}\text { Psychiatric hospitalization - } \\
\text { mother }\end{array}$ & & & \\
\hline $\begin{array}{l}\text { Psychiatric hospitalization - } \\
\text { father }\end{array}$ & & & \\
\hline $\begin{array}{l}\text { Alcohol and/or drug use - } \\
\text { mother }\end{array}$ & & & \\
\hline $\begin{array}{l}\text { Alcohol and/or drug use }- \\
\text { father }\end{array}$ & & & \\
\hline $\begin{array}{l}\text { Prenatal drinking or drug } \\
\text { use }\end{array}$ & & & & \\
\hline Present (1) or Absent $(0)$ & & & \\
\hline
\end{tabular}

Notes:

\section{Broken home or family transitions}

\begin{tabular}{|l|l|l|l|l|}
\hline Parental separation & & & & \\
\hline Parental divorce & & & & \\
\hline
\end{tabular}




\begin{tabular}{|l|l|l|l|l|}
\hline Single parent & & & & \\
\hline Parental re-marriage & & & & \\
\hline $\begin{array}{l}\text { Frequent moving (i.e., } \\
\text { residences, schools) }\end{array}$ & & & & \\
\hline $\begin{array}{l}\text { Frequent change in parental } \\
\text { figures or partners }\end{array}$ & & & & \\
\hline Present (1) or Absent (0) & & & \\
\hline
\end{tabular}

Notes:

10. Involvement with alternative care

\begin{tabular}{|l|l|l|l|l|}
\hline Child welfare agency & & & & \\
\hline Foster care & & & & \\
\hline Adopted & & & & \\
\hline $\begin{array}{l}\text { Other institutional } \\
\text { involvement } \\
\text { (specify: }\end{array}$ & & & & \\
\hline Present (1) or Absent (0) & & & \\
\hline
\end{tabular}

Notes:

\section{Trauma factors}

11. Trauma

\begin{tabular}{|l|l|l|l|l|}
\hline Sexual abuse & & & & \\
\hline Physical abuse & & & & \\
\hline Verbal/emotional abuse & & & & \\
\hline Witnessed sexual abuse & & & & \\
\hline Witnessed physical abuse & & & & \\
\hline
\end{tabular}




\begin{tabular}{|l|l|l|l|l|}
\hline $\begin{array}{l}\text { Witnessed } \\
\text { verbal/emotional abuse }\end{array}$ & & & & \\
\hline Neglect & & & & \\
\hline Other trauma (specify) & & & & \\
\hline Present (1) or Absent (0) & & & \\
\hline
\end{tabular}

Notes 


\section{References}

Akinwande, M. O., Dikko, H. G., \& Samson, A. (2015). Variance inflation factor as a condition for the inclusion of suppressor variable(s) in regression analysis. Open Journal of Statistics, 05(07), 754-767. https://doi.org/10.4236/ojs.2015.57075

American Psychiatric Association. (2013). Diagnostic and statistical manual of mental disorders (5th Ed.). Washington, DC: American Psychiatric Association.

Bergman, L. R., \& Andershed, A.K. (2009). Predictors and outcomes of persistent or age-limited registered criminal behavior: A 30-year longitudinal study of a Swedish urban population. Aggressive Behavior, 35(2), 164-178. https://doi.org/10.1002/ab.20298

Blomhoff, S., Seim, S., \& Friis, S. (1990). Can prediction of violence among psychiatric inpatients be improved? Hospital \& Community Psychiatry, 41(7), 771-775.

Bonta, J., Rugge, T., \& Dauvergne, M. (2003). The reconviction rate offederal offenders 2003 02. Retrieved from https://www.publicsafety.gc.ca/cnt/rsrcs/pblctns/rcnvctn-rt-fdrl/indexen.aspx

Brennan, P. A., Mednick, S. A., \& Hodgins, S. (2000). Major mental disorders and criminal violence in a Danish birth cohort. Archives of General Psychiatry, 57(5), 494-500. https://doi.org/10.1001/archpsyc.57.5.494

Broderick, C., Azizian, A., Kornbluh, R., \& Warburton, K. (2015). Prevalence of physical violence in a forensic psychiatric hospital system during 2011-2013: Patient assaults, staff assaults, and repeatedly violent patients. CNS Spectrums, 20(3), 319-330. https://doi.org/10.1017/S1092852915000188

Bruce, M., \& Laporte, D. (2015). Childhood trauma, antisocial personality typologies and recent violent acts among inpatient males with severe mental illness: Exploring an explanatory 
pathway. Schizophrenia Research, 162(1-3), 285-290.

https://doi.org/10.1016/j.schres.2014.12.028

Charette, Y., Crocker, A. G., Seto, M. C., Salem, L., Nicholls, T. L., \& Caulet, M. (2015). The National Trajectory Project of individuals found not criminally responsible on account of mental disorder in Canada. Part 4: Criminal recidivism. The Canadian Journal of Psychiatry, 60(3), 127-134. https://doi.org/10.1177/070674371506000307

Clarke, A. D. B., \& Clarke, A. M. (1984). Constancy and change in the growth of human characteristics. Journal of Child Psychology and Psychiatry, 25(2), 191-210. https://doi.org/10.1111/j.1469-7610.1984.tb00144.x

Cohen, J. (1960). A Coefficient of Agreement for Nominal Scales. Educational and Psychological Measurement, 20(1), 37-46. https://doi.org/10.1177/001316446002000104

Coid, J., Hickey, N., Kahtan, N., Zhang, T., \& Yang, M. (2007). Patients discharged from medium secure forensic psychiatry services: Reconvictions and risk factors. The British Journal of Psychiatry, 190(3), 223-229. https://doi.org/10.1192/bjp.bp.105.018788

Crocker, A. G., Nicholls, T. L., Seto, M. C., Charette, Y., Côté, G., \& Caulet, M. (2015). The National Trajectory Project of individuals found not criminally responsible on account of mental disorder in Canada. Part 2: The people behind the label. The Canadian Journal of Psychiatry, 60(3), 106-116. https://doi.org/10.1177/070674371506000305

Day, D. M., \& Weisner, M. (2019). Criminal trajectories: A developmental perspective. New York: New York University Press.

De Vries Robbé, M., de Vogel, V., Douglas, K. S., \& Nijman, H. L. I. (2015). Changes in dynamic risk and protective factors for violence during inpatient forensic psychiatric 
treatment: Predicting reductions in postdischarge community recidivism. Law and Human Behavior, 39(1), 53-61. https://doi.org/10.1037/lhb0000089

Douglas, K. S., Hart, S. D., Webster, C. D., \& Belfrage, H. (2013). HCR-20v3: Assessing risk of violence - User guide. Burnaby, Canada: Mental Health, Law, and Policy Institute, Simon Fraser University.

Farrington, D. P. (2015). Prospective longitudinal research on the development of offending. Australian \& New Zealand Journal of Criminology, 48(3), 314-335. https://doi.org/10.1177/0004865815590461

Farrington, D. P. (2017). Developmental criminology. In A. Brisman, E. Carrabine, \& N. South (Eds.), The Routledge Companion to Criminological Theory and Concepts (pp. 60-64). New York, NY: Routledge, Taylor \& Francis Group.

Farrington, D. P., Jolliffe, D., Loeber, R., Stouthamer-loeber, M., \& Kalb, L. M. (2001). The concentration of offenders in families, and family criminality in the prediction of boys' delinquency. Journal of Adolescence, 24(5), 579-596.

https://doi.org/10.1006/jado.2001.0424

Fazel, S., Grann, M., Carlström, E., Lichtenstein, P., \& Långström, N. (2009). Risk factors for violent crime in schizophrenia: A national cohort study of 13,806 patients. The Journal of Clinical Psychiatry, 70(3), 362-369. https://doi.org/10.4088/JCP.08m04274

Harris, G. T., Rice, M. E., \& Quinsey, V. L. (1993). Violent recidivism of mentally disordered offenders: The development of a statistical prediction instrument. Criminal Justice and Behavior, 20(4), 315-335. https://doi.org/10.1177/0093854893020004001

Hodgins, S. (2008). Violent behaviour among people with schizophrenia: A framework for investigations of causes, and effective treatment, and prevention. Philosophical 
Transactions of the Royal Society B: Biological Sciences, 363(1503), 2505-2518. https://doi.org/10.1098/rstb.2008.0034

Hodgins, S., Cree, A., Alderton, J., \& Mak, T. (2008). From conduct disorder to severe mental illness: Associations with aggressive behaviour, crime and victimization. Psychological Medicine, 38(07). https://doi.org/10.1017/S0033291707002164

Hogan, N. R., \& Olver, M. E. (2016). Assessing risk for aggression in forensic psychiatric inpatients: An examination of five measures. Law and Human Behavior, 40(3), 233-243. https://doi.org/10.1037/lhb0000179

Hoptman, M. J., Yates, K. F., Patalinjug, M. B., Wack, R. C., \& Convit, A. (1999). Clinical prediction of assaultive behavior among male psychiatric patients at a maximum-security forensic facility. Psychiatric Services, 50(11), 1461-1466.

Hosmer, D. W., \& Lemeshow, S. (2004). Applied Logistic Regression. Retrieved from http://ebookcentral.proquest.com/lib/ryerson/detail.action?docID=215160

Kelly, E. L., Subica, A. M., Fulginiti, A., Brekke, J. S., \& Novaco, R. W. (2015). A crosssectional survey of factors related to inpatient assault of staff in a forensic psychiatric hospital. Journal of Advanced Nursing, 71(5), 1110-1122. https://doi.org/10.1111/jan.12609

Kim-Cohen, J., Caspi, A., Moffitt, T. E., Harrington, H., Milne, B. J., \& Poulton, R. (2003). Prior juvenile diagnoses in adults with mental disorder: Developmental follow-back of a prospective-longitudinal cohort. Archives of General Psychiatry, 60(7), 709-717. https://doi.org/10.1001/archpsyc.60.7.709 
Krakowski, M. I., Convit, A., Jaeger, J., Shang, L., \& Volavka, J. (1989). Neurological impairment in violent schizophrenic inpatients. The American Journal of Psychiatry; Washington, 146(7), 849-853.

Landis, J. R., \& Koch, G. G. (1977). The measurement of observer agreement for categorical data. Biometrics, 33(1), 159-174. https://doi.org/10.2307/2529310

Linhorst, D. M., \& Scott, L. P. (2004). Assaultive behavior in state psychiatric hospitals: Differences between forensic and nonforensic patients. Journal of Interpersonal Violence, 19(8), 857-874. https://doi.org/10.1177/0886260504266883

Moffitt, T. E. (1993). Adolescence-limited and life-course-persistent antisocial behavior: A developmental taxonomy. Psychological Review, 100(4), 674-701. https://doi.org/10.1037//0033-295X.100.4.674

Moffitt, T. E., \& Caspi, A. (2001). Childhood predictors differentiate life-course persistent and adolescence-limited antisocial pathways among males and females. Development and Psychopathology, 13(2), 355-375.

Oakley, C., Harris, S., Fahy, T., Murphy, D., \& Picchioni, M. (2016). Childhood adversity and conduct disorder: A developmental pathway to violence in schizophrenia. Schizophrenia Research, 172(1-3), 54-59. https://doi.org/10.1016/j.schres.2016.01.047

Penney, S. R., Marshall, L. A., \& Simpson, A. I. F. (2016). The assessment of dynamic risk among forensic psychiatric patients transitioning to the community. Law and Human Behavior, 40(4), 374-386. https://doi.org/10.1037/lhb0000183

Philipse, M. W. G., Koeter, M. W. J., van der Staak, C. P. F., \& van den Brink, W. (2006). Static and dynamic patient characteristics as predictors of criminal recidivism: A prospective 
study in a Dutch forensic psychiatric sample. Law and Human Behavior, 30(3), 309-327. https://doi.org/10.1007/s10979-006-9013-4

Rea, L. M., \& Parker, R. A. (2005). Designing and conducting survey research: A comprehensive guide (3rd ed.). San Francisco: Jossey-Bass.

Reavis, J. A., Looman, J., Franco, K. A., \& Rojas, B. (2013). Adverse childhood experiences and adult criminality: How long must we live before we possess our own lives? The Permanente Journal, 17(2), 44-48. https://doi.org/10.7812/TPP/12-072

Robins, L. N., \& Price, R. K. (1991). Adult disorders predicted by childhood conduct problems. Psychiatry; Washington, Etc., 54(2), 116-132.

Schore, A. N. (2002). Dysregulation of the right brain: A fundamental mechanism of traumatic attachment and the psychopathogenesis of posttraumatic stress disorder. Australian \& New Zealand Journal of Psychiatry, 36(1), 9-30. https://doi.org/10.1046/j.14401614.2002.00996.x

Sedgwick, O., Young, S., Das, M., \& Kumari, V. (2016). Objective predictors of outcome in forensic mental health services-a systematic review. CNS Spectrums, 21(6), 430-444. https://doi.org/10.1017/S1092852915000723

Smith, C., \& Thornberry, T. P. (1995). The relationship between childhood maltreatment and adolescent involvement in delinquency. Criminology, 33(4), 451-481. https://doi.org/10.1111/j.1745-9125.1995.tb01186.x

Ward, A. K., Day, D. M., Bevc, I., Ye Sun, Rosenthal, J. S., \& Duchesne, T. (2010). Criminal trajectories and risk factors in a Canadian sample of offenders. Criminal Justice and Behavior, 37(11), 1278-1300. https://doi.org/10.1177/0093854810379702 
Webster, C. D., Douglas, K. S., Eaves, D., \& Hart, S. D. (1997). HCR-20: Assessing risk for violence (version 2). Vancouver, Canada: Mental Health, Law, and Policy Institute, Simon Fraser University. 